\title{
PLP-Dependent Enzymes: a Potent Therapeutic Approach for Cancer and Cardiovascular Diseases
}

\author{
Ashraf S. El-Sayed and Ahmed A. Shindia \\ Microbiology Department, Faculty of Science, Zagazig University, Zagazig, \\ Egypt
}

\section{Introduction}

The evolution on the field of biotechnology and proteomics create a novel therapeutic field (Enzymo-therapy) for treatment of various types of disease, particularly in the last fifty years. Exploitation of enzymes as anticancer, anti-cardiovascular, anticoagulants, antimicrobials and antioxidants (Vellard, 2003) was absolutely approved by Food and Drug Administration (FDA). Practically, almost of tumor cells were reported to be auxotrophs for L-methionine, glutamine, asparagine and arginine, due to the absence of intrinsic enzymatic systems synthesizing these amino acids, thus it depends for their growth and proliferation on the exogenous supply of these amino acids, that usually from diets (Hoffman and Erbe, 1976, Mecham et al., 1983, Pasut et al., 2007, El-Sayed, 2010). Consequently, L-methioninase, L-glutaminase, L-asparaginase and arginine deiminase were frequently used as common anticancer agents by sequestering their corresponding amino acids from the blood plasma (Hoffman, 1985, Klimberg and McClellan, 1996, Agrawal et al., 2003, Cheng et al., 2005).

Additionally, hyperaccumulation of certain metabolic intermediates as homocysteine and cystathionine usually associated with various cardiovascular diseases and complex disorders (Zou and Banerjee, 2005, Wang and Hegele, 2003). Cystathionine $\beta$-synthase and cystathionine $\gamma$-lyase are potential for sequestering homocysteine and cystathionine via transsulfuration metabolic pathways for production of glutathione and other antioxidants, so, these enzymes were described as anti-cardiovascular agents (Stipanuk, 2004, Zhu et al., 2008).

Unlike traditional approaches, Enzymo-therapy seems to be the promising therapeutic technology for their great specificity and affinity towards a clue substrate on specific metabolic pathway. However, the structural and conformational complexity of these enzymes makes it more vulnerable to extrinsic parameters, modulators, immunogenicity and proteolysis (Tan et al., 1996, Sun et al., 2003, Pasut et al., 2007). In addition, purification and formulation of these therapeutic enzymes, due to the economic expenses may add further complications.

Therefore, the various approaches for stabilization of these enzymes in situ and decreasing their immunogenicity were the objective of this context. The structural and catalytic identity of pyridoxal phosphate enzymes, molecular aspects to enhance their therapeutic potentiality, in addition to our prospectives will be exploited. 


\section{Pyridoxal 5'-phosphate dependent enzymes: classification and catalytic identities}

Pyridoxal 5'-Phosphate (PLP) dependent enzymes, a group of versatile enzymes including about 145 distinct enzyme, $4 \%$ of the total cellular enzymatic activities (www.brenda.com) (Thornton et al., 2000, Percudani and Peracchi, 2003) which mainly uses PLP as covalent coenzyme. PLP is an active phosphorylated derivative of vitamin B6 (pyridoxine) (Heyl et al., 1951). According to the international biochemical, molecular classification of enzymes (Enzyme Commission) (www.chem.qmul.ac.uk/iubmb), PLP-dependent enzymes were distributed in to five groups; 1- Oxido-reductase (EC 1; one enzyme), 2-Transferase (EC 2; eighty enzymes), 3- Hydrolase (EC 3; two enzymes), 4-Lyase (EC 4; Forty nine enzyme), and 5-Isomerase (EC 5; Thirteen enzyme) as totally 145 enzyme (Grishin et al., 1995, Percudani and Peracchi, 2003) as shown in Fig.1.

Practically, all the PLP-dependent-enzymes are mainly involved in amino acids transformation as decarboxylation, transamination, racemization, $\beta, \gamma$-elimination and $\beta, \gamma-$ substitution (Percudani and Peracchi, 2003). The multiple functional catalytic modes of PLPenzymes according to the position of net reaction were summarized in Table 1. PLP coenzyme has a pivotal role in catalysis of various enzymatic reactions. Pyridoxal phosphate can be synthesized de novo from preexisting precursor in bacteria (Brewke and Leistner, 2001), fungi (Bean et al., 2001, Ehrenshaft and Daub, 2001) and plants (Galperin and Koonin, 1997) from erythrose 4-phosphate, pyruvate and D-glyceraldhyde 3-phosphate. However, in human PLP cannot be synthesized de novo, it must be supplemented from the diet as pyridoxine, pyridoxamine and/or pyridoxal. PLP can be formed from pyridoxal via phosphorylation by action of kinase (PdxK; EC. 2.7.1.35), from oxidation of pyridoxamine/ pyridoxine by oxidase (EC. 1.4.3.5) (Choi et al., 1983, Bahn et al., 2002). Structurally, aldehyde group of PLP are bound covalently as internal aldimine (Schiff base)/ imine linkage to the $\varepsilon$-amino group of lysine residues, close to $N$-terminus (Lopez et al., 2010) as in Fig. (2).

The role of PLP, during catalysis, is to reduce the energy for conversion of amino acids substrates to a zwitterionic carbonion (Richard and Amyes, 2004), substantially the apoenzyme catalyze the cleavage of substrate target bond yielding the product as reviewed by Richard et al. (2011). Regarding to the native internal aldimine of PLP-enzyme, the catalytic process started with formation of external aldimine linkage of amino group of substrate and pyridoxal phosphate coenzyme forming coenzyme-substrate Schiff base, replacing the $\varepsilon$-amino group of lysine-enzyme (Schirch et al., 1993).This external aldimine of Co-enzyme-substrate Schiff base is the common intermediate for all PLP-dependent enzymes. Interestingly, pyridoxal phosphate without apo-enzyme, can slowly mediate many of reactions while the enzyme can ensure the substrate specificity and catalysis (Toney, 2005, Lopez et al., 2010), that justifies the lack of apoenzyme activity, with potentiality to recover its catalytic state upon supplementation by external PLP (El-Sayed, 2011). Since the formation of external aldimine, the pyridoxal phosphate is bounded tightly to the apoenzyme via nine hydrogen bonds (Johnson et al., 1990, Palm et al., 1990). The PLP extremely withdraw electrons, stabilizing the negative charge at a-carbon (carbanion) of the substrate as transition state that commonly referred as Quinonoid intermediates (Metha and Christen, 2000, Hult and Berglund, 2007). The catalytic promiscuity of PLP-dependent enzymes mainly depends on the mechanistic consequence of quinonoid intermediates (Alexander et al., 1994, Toney, 2005) as shown in Fig. (3). 
Depending of crystallographic structures and topological studies, PLP-dependent enzymes were categorized in to five distinct folds (I-V) (Alexander et al., 1994, John, 1995, Jansonius, 1998) as illustrated in Table 2. The five independent fold types of PLP-enzymes were: Fold type I; Aspartate Aminotransferase (AAT) family; the most functionally diverse type containing $\alpha$ and $\gamma$-families of PLP-enzymes in which the internal aldimine was formed at lysine of $N$-terminus of the short helix at $\beta$-strand (Percudani and Peracchi, 2003). On AAT family, pyridine nitrogen is protonated and stabilized by interaction with enzyme aspartic and glutamic acid (Casanovas et al., 2009). Methionine $\gamma$-lyase, cystathionine $\beta$-synthase, cystathionine $\gamma$-lyase were belongs to this family. Fold type II; Tryptophan Synthase $\beta$ family, this family represented tryptophan synthase (Hyde et al., 1988), threonine deaminase (Gallagher et al., 1998) and O-acetylserine sulfhydrylase (Burkhard et al., 1998). The internal aldimine was at lysine residues of a-helix on the $N$-terminal domain. The apoenzyme was stabilized by interaction of its serine and threonine residues with pyridine ring of PLP (Percudani and peracchi, 2003). Fold type III; Alanine Racemase family; that represented by alanine racemase (Shaw et al., 2000), ornithine decarboxylase (Kern et al., 1999). Physically, the pyridine ring PLP, coenzyme, was interacted with NH moiety of arginine residues of apo-enzyme (Le-Magueres et al., 2005). Fold type IV; D-Amino Acid Aminotransferase family, that involve D-amino acid aminotransferase (Sugio, 1995), branched chain amino acid amino transferase (Okada et al., 1997) and 4-amino-4deoxychorismate lyase (Nakai et al., 2000) as reviewed by Denesyuk et al. (2002). Like Type I, pyridine of PLP was interacted with glutamic acid of apoenzyme by hydrogen bonds (Sugio, 1995). Fold type V; Glycogen Phosphorylase Family; that contains glycogen phosphorylase (Sprang and Fletterick, 1979, Palm et al., 1990) and maltodextrin phosphorylase (Watson et al., 1999).

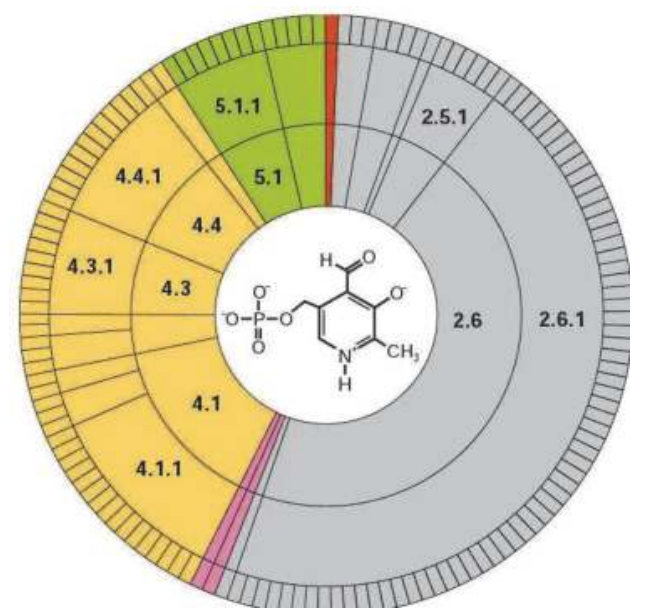

PLP-dependent enzymes were within five classes according to enzyme classification system (Enzyme Commission (EC) 1-Oxidoreductases, one enzyme (Red), 2-Transferase, 80 enzyme (faint blue), 3Hydrolase, two enzymes (faint red), 4-Lyase, 49 enzyme (yellow) and 5-Isomearse, 13 enzyme (green). The catalytic diversity of PLP-dependent enzymes was described by Thornton et al. (2000) and Percudani and Peracchi (2003).

Fig. 1. Pyridoxal Phosphate Dependent Enzymes. 


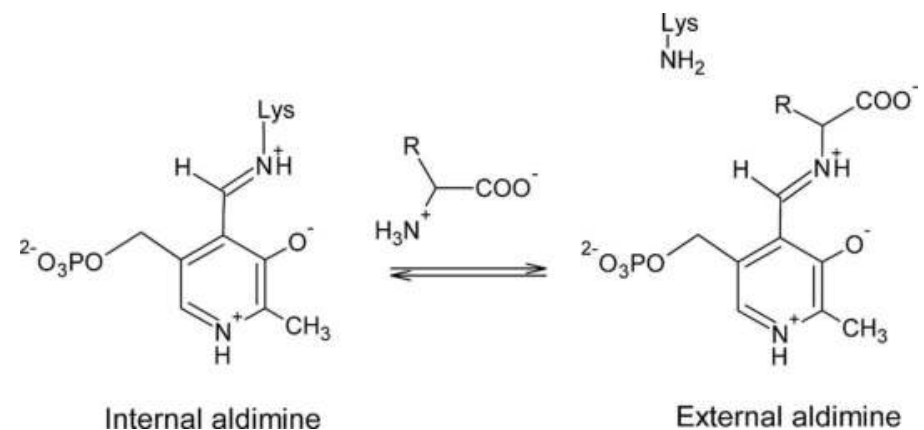

Fig. 2. Internal and External aldimine linkage of Pyridoxal Phosphate with enzyme and substrate, respectively

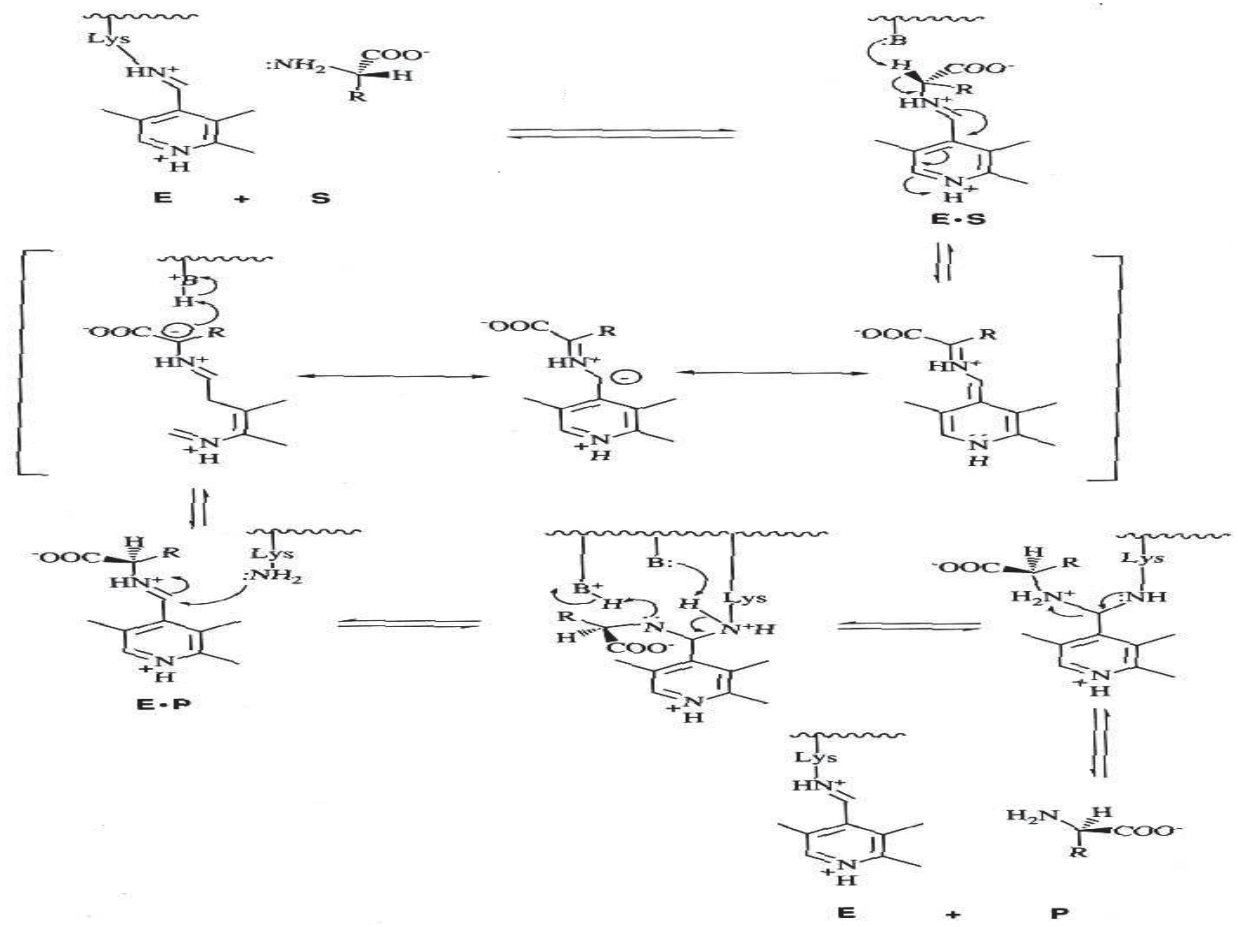

Fig. 3. Mechanism of PLP-enzyme catalysis via Quinonoid intermediates. 


\begin{tabular}{|c|c|c|c|}
\hline $\begin{array}{c}\text { Reaction } \\
\text { site }\end{array}$ & Reaction type & Mechanism of Reaction & $\begin{array}{c}\text { Example of } \\
\text { PLP-Enzyme }\end{array}$ \\
\hline \multirow[t]{4}{*}{$\begin{array}{c}\text { a- } \\
\text { Position }\end{array}$} & Racemization & $\mathrm{HOOC} \backslash \stackrel{\mathrm{H}}{\text { s }}$ & $\begin{array}{l}\text { Alanine } \\
\text { racemase }\end{array}$ \\
\hline & $\begin{array}{c}\text { Decarboxyla- } \\
\text { tion }\end{array}$ & $\longrightarrow \mathrm{R}-\stackrel{\mathrm{C}}{\mathrm{C}}-\mathrm{H}+\mathrm{CO}_{2}$ & $\begin{array}{c}\text { Ornithine } \\
\text { decarboxylase }\end{array}$ \\
\hline & $\begin{array}{c}\text { Transamina- } \\
\text { tion }\end{array}$ & $\mathrm{R}_{1}-\left.\right|_{\mathrm{CH}} ^{\mathrm{COOH}}+\mathrm{R}_{2}-\left.\right|_{\mathrm{C}} ^{\mathrm{COOH}} \longrightarrow \mathrm{R}_{2}-\left.\right|_{\mathrm{NH}_{2}} ^{\mathrm{COOH}}+\mathrm{R}_{1}-\prod_{0}^{\mathrm{C}}$ & $\begin{array}{c}\text { Tyrosine } \\
\text { aminotransferase }\end{array}$ \\
\hline & Elimination & $\int_{\mathrm{NH}_{2}}^{\mathrm{COOH}} \longrightarrow \mathrm{H}_{2} \mathrm{~N}-\mathrm{C}^{\mathrm{H}}-\mathrm{COOH}+\mathrm{R}$ & $\begin{array}{l}\text { Serine hydroxyl- } \\
\text { methyltransferase }\end{array}$ \\
\hline \multirow[t]{2}{*}{$\beta$-Position } & Replacement & $\mathrm{R}_{1}-\stackrel{\mathrm{H}_{2}}{\mathrm{C}}-\left.\right|_{\mathrm{NH}_{2}} ^{\mathrm{COOH}} \longrightarrow \mathrm{R}_{2}-{ }_{\mathrm{NH}_{2}}^{\mathrm{C}_{2}}-{ }_{\mathrm{CH}}^{\mathrm{COOH}}$ & $\begin{array}{l}\text { Tryptophan } \\
\text { synthase }\end{array}$ \\
\hline & Elimination & 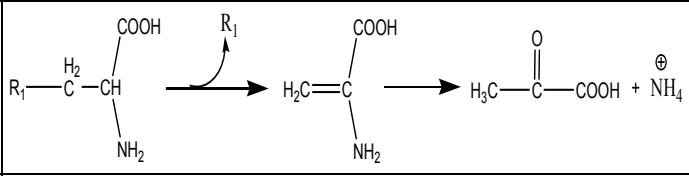 & $\begin{array}{c}\text { Serine } \\
\text { dehydratase }\end{array}$ \\
\hline \multirow[t]{2}{*}{$\gamma$-Position } & Replacement & $\mathrm{R}_{1}-\mathrm{C}_{\gamma}^{\mathrm{H}_{2}}-\mathrm{C}_{\mathrm{NH}}^{\mathrm{H}}-\mathrm{C}_{2}-\mathrm{CH}_{\mathrm{C}}^{\mathrm{COOH}}-\mathrm{C}^{\mathrm{H}}-\left.\right|_{\mathrm{NH}_{2}} ^{\mathrm{COOH}}$ & $\begin{array}{l}\text { Cystathionine } \\
\text { Y-synthase }\end{array}$ \\
\hline & Elimination & $\mathrm{R}_{1}-\stackrel{\mathrm{H}_{2}}{\mathrm{C}}-\stackrel{\mathrm{H}_{2}}{\mathrm{C}}-\left.\right|_{\mathrm{CH}} ^{\mathrm{COOH}} \longrightarrow \mathrm{R}_{1}+\mathrm{H}_{3} \mathrm{C}-\stackrel{\mathrm{H}_{2}}{\mathrm{C}}-\stackrel{\mathrm{O}}{\mathrm{C}}-\mathrm{COOH}+\stackrel{\oplus}{\mathrm{NH}_{4}}$ & $\begin{array}{c}\text { Methionine } \\
\gamma \text {-lyase }\end{array}$ \\
\hline
\end{tabular}

Table 1. Functional catalytic modes of PLP-enzymes according to the position of net reaction 


\begin{tabular}{|c|c|c|c|}
\hline No. & Fold Type I & No. & \\
\hline 1 & Glycine dehydrogenase & 50 & Tyrosine decarboxylase \\
\hline 2 & Glycine hydroxymethyltransferase & 51 & Glutamate decarboxylase b \\
\hline 3 & Threonine aldolase & 52 & Histidine decarboxylase $b$ \\
\hline 4 & Trptophanase & 53 & Ornithine decarboxylase 1 \\
\hline 5 & Tyrosine phenol lyase & 54 & Arginine decarboxylase 1 \\
\hline 6 & Selenocysteine lyase & 55 & Lysine decarboxylase \\
\hline 7 & Glyoxylate aminotransferase & 56 & Allinase \\
\hline 8 & Serine aminotransferase & & \\
\hline 9 & Phosphoserine aminotransferase & & \\
\hline 10 & Amino ketobutyrate CoA ligase & & Fold Type II \\
\hline 11 & Aminolevulinate Synthase & 1 & Aminocyclopropane-carboxyl deaminase \\
\hline 12 & Amino oxononanoate synthase & 2 & Tryptophan synthase $\beta$ \\
\hline 13 & Serine palmitoyltransferase & 3 & Cystathionine $\beta$-synthase \\
\hline 14 & Kvnureninase & 4 & O-Acetylserine sulfhydrylase \\
\hline 15 & Isopenicillin $N$-epimerase & 5 & D-Serine dehydratase \\
\hline 16 & Cysteine desulfurase & 6 & L-serine dehydratase \\
\hline 17 & Splicing protein SPL1 & 7 & Threonine dehydratase \\
\hline 18 & Cystathionine $\gamma$-Synthase & 8 & Threonine synthase 1 \\
\hline 19 & O-Succinylhomoserine sulhydrase & 9 & Diaminopropionate lyase \\
\hline 20 & Methionine $\gamma$-Lyase & 10 & Threonine synthase 2 \\
\hline 21 & Cystathionine $\gamma$-Lyase & 11 & D-Alanine aminotransferase \\
\hline 22 & Cystathionine $\beta$-Lyase & 12 & Amino deoxychorismate lyase \\
\hline 23 & Aspartate aminotransferase a & 13 & Branched amino acid aminotransferase \\
\hline 24 & $\begin{array}{l}\text { Aromatic amino acid } \\
\text { aminotransferase }\end{array}$ & & \\
\hline 25 & Tyrosine aminotransferase & & \\
\hline 26 & Alanine aminotransferase & & Fold Type III \\
\hline 27 & malY gene product & 1 & Ornithine decarboxylase 2 \\
\hline 28 & Phenylpuruvate aminotransferase & 2 & Diaminopimelate decarboxylase \\
\hline 29 & $\begin{array}{l}\text { Aminocyclopropane carboxylate } \\
\text { synthase }\end{array}$ & 3 & Arginine decarboxylase \\
\hline 30 & Rhizopine regulatory protein & & alanine racemase \\
\hline 31 & Aspartate aminotransferase $b$ & & \\
\hline 32 & Aspartate aminotransferase c & & \\
\hline 33 & $\begin{array}{l}\text { Histidinol phosphate } \\
\text { aminotransferase }\end{array}$ & & Fold Type IV \\
\hline 34 & cobC gene product & 1 & D-amino acid aminotransferase \\
\hline 35 & Valine-Pyruvate aminotransferase & 2 & $\begin{array}{l}\text { branched chain amino acid amino } \\
\text { transferase }\end{array}$ \\
\hline 36 & Acetylornithine aminotransferase & 3 & 4-amino-4-deoxychorismate lyase \\
\hline 37 & Succinylornithine aminotransferase & & \\
\hline 38 & Ornithine aminotransferase & & \\
\hline 39 & $\begin{array}{l}\text { Alanine glyoxylate } \\
\text { aminotransferase }\end{array}$ & & \\
\hline 40 & Dialkylglycine decarboxylase & & Fold type $\mathrm{V}$ \\
\hline
\end{tabular}




\begin{tabular}{|c|l|l|l|}
\hline 41 & Alanine pyruvate aminotransferase & 1 & Glycogen phosphorylase \\
\hline 42 & $\begin{array}{l}\text { Aminooxononanoate } \\
\text { aminotransferase }\end{array}$ & 2 & Maltodextrin phosphorylase \\
\hline 43 & DNTP hexose aminotransferase & & \\
\hline 44 & $\begin{array}{l}\text { Glutamate semialdehyde } \\
\text { aminomutase }\end{array}$ & & \\
\hline 45 & Aminobutyrate aminotransferase & & \\
\hline 46 & Lysine E-aminotransferase & & \\
\hline 47 & $\begin{array}{l}\text { Diaminobutanoate } \\
\text { aminotransferase }\end{array}$ & & \\
\hline 48 & Glutamate decarboxylase a & & \\
\hline 49 & Histidine decarboxylase a & & \\
\hline
\end{tabular}

Table 2. Families of Pyridoxal Phosphate dependent enzymes

No hydrogen bonds between pyridine nitrogen and apoenzyme (Percudani and Percacchi, 2003). The systematic and catalytic promiscuity of the five fold types PLP-dependent enzymes as adopted by Metha and Christen (2000) and Percudani and Peracchi (2003), were illustrated in Table 2.

Regarding to our previous work (Khalaf and El-Sayed, 2009, El-Sayed, 2009, 2010, 2011a, b), the subsequent section was focused on the metabolic interactions of sulfur containing amino acid by PLP-dependent enzymes of Aspartate Aminotransferase Family.

\section{Metabolic interactions of sulfur-containing amino acids by PLP-dependent enzymes: Biochemical identity of normal and tumor cells}

Sulfur-containing amino acids are pivotal compounds for almost of metabolic cellular process. In contrary to humans, plants and microorganisms can synthesize their sulfur containing amino acids from the inorganic precursor as sulfate, sulfite and sulfide via reduction or activation (Beinert, 2000, Kessler, 2006). In humans, methionine and cysteine were described as conditional essential amino acids for normal various biological aspects (Baylin et al., 1998, Davis and Uthus, 2004). The prominent sulfur containing amino acids on living cell are cysteine and methionine, that crucially incorporated on the synthesis of Coenzyme, vitamins, epigenetic DNA modulators, DNA stabilizers and antioxidants (El-Sayed, 2010 and Cellarier et al., 2003). Additionally, cysteine is the essential source for $\mathrm{H}_{2} \mathrm{~S}$ biogenesis that critically acts as neuro-modulators, cardio-protector, relaxing muscle regulators, and vasodiolator for vascular system (Wang, 2002, Kimura, 2010, Predmore and Lefer, 2010 and Gadalla and Snyder, 2010). The general metabolic interactions of sulfur containing amino acids and their derivative by PLP-enzymes were illustrated in Fig. (3). Methionine can be metabolized via different ways that collectively regulated by PLPdependent enzymes as methionine $\gamma$-lyase, cystathionine $\beta, \gamma$-synthases and cystathionine $\beta$, $\gamma$-lyases. In plants and microbes, methionine can be undergoes oxidative deamination/ demethiolation forming methanethiol, a-ketobutyrate and ammonia (Tanaka et al., 1977) via the action of L-methioninase. L-Methioninase was frequently reported as a substrate induced extracellular enzyme for various microbial cultures (Tanaka et al., 1977, Soda et al., 1983; Nikulin et al., 2008, Khalaf and El-Sayed, 2009), while it is absent in mammalian cells (Cooper, 1983). Biochemically, methionine was activated by methionine adenosyltransferase forming $S$-adenosylmethionine as a key intermediate for the following metabolic pathways; 


\section{Transmethylation pathway and methionine synthesis}

$S$-Adenosylmethionine undergoes de-methylation by glycine- $N$-methyltransferase forming $S$-adenosyl homocysteine (Luka et al., 2006). This reaction is the source for more than 100 biological methylation reactions including epigenetic DNA regulation and protein posttranslational modifications, in living cell (Choi and Mason, 2002) Moreover, in microbial cells, the methyl group from adenosylmethionine can switch the formation of Siroheme via methylation followed by oxidation of Uroporphyrinogen II (Thomas et al., 1997, Hansen et

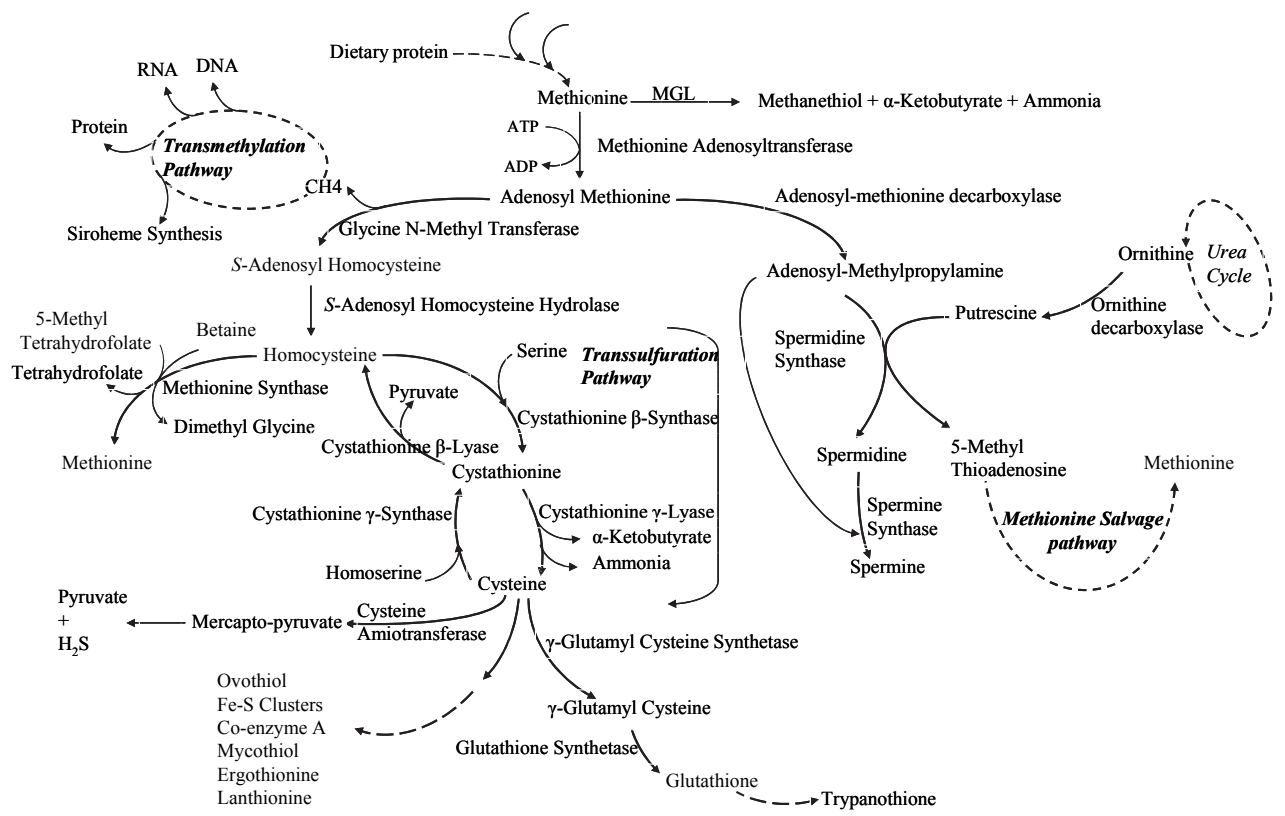

Fig. 3. Metabolic Interactions of sulfur-containing amino acids, as supplied from the diet or intracellular, via different cellular pathways. Except human, L-methionine was undergoes oxidative deamination and demethiolation by L-methioninase (EC 4.4.1.11) in various microorganisms and plants. In all living cells, adenosyl methionine, activated form of Lmethionine, was implicated in various pathways: 1- Transmethylation, adenosylmethionine by glycine $\mathrm{N}$-methyltransferase is demethylated to adenosyl-homocysteine that involved in methylation of DNA, RNA, and protein. 2- Transsulfuration pathway, forming glutathione and trypanothione as cellular antioxidants, cysteine was involved on formation of several Scontaining compounds. 3- Polyamine synthesis, S-adenosylmethionine was decarboxylated by decarboxylase forming adenosyl methylpropylamine that condensate with putrescine forming spermidine by spermidine synthase, then forming spermine by spermine synthase. 
al., 1997). Physiologically, tumors are genetically abnormal cells with uncontrolled rapidly growth and proliferation, for mutation on some genes encoding amino acids metabolizing enzymes, comparing to the corresponding normal cells (Hoffman, 1985). Elevated requirements of methionine are the common biochemical criteria by tumor cells comparing to corresponding normal ones, to fulfill their high protein synthesis and regulation of DNA expression (Stern et al., 1984, Swisher et al., 2009). Practically, hypermethylation of DNA is usually correlates with transcriptional silencing of many of tumor suppressor genes, $\mathrm{P}_{53}$ genes, thus disrupting DNA repairing systems and cell signaling modulators (Jones and Baylin, 2002, Santini et al., 2001) as reviewed by El-Sayed (2010). Also, methylation of tumor DNA change the identity of CpG islands, thus altering the expression of DNA repairing and apoptosis controlling genes (Sun et al., 1997, Matsukura et al, 2003) and changing of CpG islands (Swisher et al., 2009). On other hand, suppression of methionine synthase genes are a reliable cellular criteria in various cells as bladder, breast, kidney, lung and hematological tumors (Mecham et al., 1983, Hoffman, 1985, Kreis and Goodenow, 1978), thus it described as methionine dependent cells. In contrast, the normal cells have an active methionine synthase with the ability to form methionine from homocysteine in the presence of methyl tetrahydro folate and betaine as methyl group donors (Kenyon et al., 2002). Consequently, the tumor cells have no ability to grow on homocysteine, comparing to the normal growth of healthy cells. The different argumentations for methionine dependency of tumor cells and biochemical identity of L-methioninase as therapeutic agent were comprehensively interpreted by our previous studies (El-Sayed, 2010).

\section{Polyamines synthesis}

S-Adenosylmethionine was decarboxylated by adenosylmethionine decarboxylase forming S-adenosyl-methylpropylamine (Gilmour, 2007) that subsequently reacts with putrescine forming spermidine by spermidine synthase (Fig. 3). Subsequently, S-adenosyl-methyl propylamine react with spermidine forming spermine by action of spermine synthase (Martinez-Lopez et al., 2008). Putrescine residues are catabolically products of ornithine/ arginine as intermediates of urea cycle by action of decarboxylases. Polyamines are biogenic molecules that tightly bound to the poly-anionic macromolecules as DNA, RNA and phospholipids (Igarashi et al., 1982), regulating the gene expression and protein processing. Biochemically, it crucially involved in stabilization of DNA: Chromatin conformational structures (Davidson et al., 1999), reprogramming of some genes by translational frameshifting mechanism and expression of the targeted overlapped open reading frames (such as nuclear phospholipids $\mathrm{P}_{53}$ ) (Coffino, 2000). Also, it essentially interact with membrane phospholipids regulating the membrane linked enzyme transporters (Moruzzi et al., 1993), maintaining the proper membrane potentials. In contrast, high levels of polyamines usually associated with high carcinogenesis of skin, breast, liver, kidney (O'Brien, 1976, Pegg, 1988) and over apoptosis (Hoet and Nemery, 2000). Practically, elevated levels of ornithine decarboxylase a pyridoxal phosphate-dependent enzyme, is significantly correlates with high ratio of polyamines that usually used as relevant carcinogenesis marker (Persson et al., 1998).

\section{Transsulfuration pathway}

Transsulfuration is the main metabolic pathway for transformation of homocysteine to glutathione, and trypanothione (Cellarier et al., 2003), involving two pyridoxal phosphate 
dependent enzymes, cystathionine $\beta$-synthase and $\gamma$-lyase (Fig. 3). By cystathionine $\beta$ synthase, homocysteine condensates with serine moiety forming cystathionine, that subsequently oxidized to cysteine, a-ketobutyrate and ammonia by cystathionine $\gamma$-lyase (Zou and Baerjee, 2005). Biochemically, transsulfuration pathway contributes in maintaining the cellular balance of cysteine-homocysteine pool that participates in about $50 \%$ of total antioxidant formation (Zhu et al., 2008). Practically, inactivation of cystathionine $\beta$-synthase causes hyperaccumulation of homocysteine that is a visual risk of cardiovascular diseases, damage to vascular endothelia (De Bree et al., 2002, Wald et al., 2002) and Alzheimer's disease (Morris, 2003). Moreover, the deficiency of cystathionine $\gamma$-lyase results in accumulation of cystathionine, known as Cystathioninuria that usually accompanied with diabetes, Down's syndrome, neuroblastoma (Wang and Hegele, 2003, Zhu et al., 2008). Glutathione was synthesized by Y-glutamylation (El-Sayed et al., 2010) of cysteine by $\gamma^{-}$ glutamyl cysteine synthetase, then complexation with glycine forming glutathione by glutathione synthetase (Cellarier et al., 2003) as reviewed by El-Sayed (2010). Trypanothione as dimmer of glutathione molecules joined by sperimidine linker, as powerful antioxidants against stress (Tover et al., 2003).

\section{Rationality of PLP dependent enzymes as antitumor and anti- cardiovascular agents}

The absolute dependence of tumor cells on the exogenous supply of plasma L-methionine, not homocysteine, due to their lacks to active methionine synthase is the biochemical target for many therapeutic strategies (Cellarier et al., 2003). Unlike the inactivity of methionine synthase in tumor cells, this enzyme was very active in normal cells ensuring their ability for synthesizing required methionine from homocysteine (Anderson, 1998). The argumentation of biochemical dependence of tumors on methionine synthase or their coenzymes for various cell lines corresponding to the normal cells was comprehensively documented (Liteplo et al., 1991; Fiskerstrand et al., 1994, El-Sayed, 2010). Several approaches were designed for triggering the methionine dependency of tumor cells, for example, starvation of the tumor cells from methionine using methionine-free diets that displays a reliable efficacy against various types of tumor cells (Goseki et al. 1992). However, this strategy is practically inefficient for many technical, therapeutical and economical considerations (Hoffman, 1985, Tan et al., 1996, Hoshiya et al., 1997). Consequently, application of L-methioninase for removal of plasma L-methionine is the potent justifiable strategy towards various methionine dependent tumor cells (Anderson, 1998 and Kokkinakis, 2006). Methionine depletions cause arresting of tumor cell growth on the late of S-G2 phase undergoing eventually apoptosis (Guo et al., 1993, Nagahama et al., 1998). Biochemically, nutrients with depleted or enriched specific amino acid affect on the growth of normal/tumor cells, according to Harper's concept of amino acid balance. Malnutrition of patient is closely associated with severe amino acid metabolic disorders, uncorrectable nitrogen balance with low activity of immune system (Nitenberg and Raynard, 2000). Interestingly, methionine/ valine depleted, tyrosine lowered and arginine enriched was the most rationalized form for inhibition of tumor growth (Chen et al., 2001, He et al., 2003). L-Methioninase was extensively tested a potent anti-proliferative enzyme towards Lewis lung (Yoshioka et al., 1998), human colon (Tan et al., 1998), glioblastoma (Kokkinakis et al., 2001), neuroblastoma (Hu and Cheung, 2009) as reviewed by Sato and Nozaki (2009) and El-Sayed (2010). Recently, Parenteral nutrition is a common cosupportive strategy for various aspects of tumor therapy (Buchman et al., 2006). 
L-Methioninase was purified and characterized from different bacterial isolates (Hoffman and Erbe, 1976; Tanaka et al., 1977, Soda et al., 1983, Nikulin et al., 2008), particularly, Pseudomonas putida enzyme that extensively structurally studied via crystallographic studies (Ito et al., 1976, Tanaka et al., 1977, Nakayama et al., 1984, Lishko et al., 1993, Motoshima et al., 2000, Kudou et al., 2007). However, the therapeutic response of bacterial enzymes usually associated with high immunogenic reactions, rapid plasma clearance and proteolysis especially with multiple dosing (Tan et al., 1996; Sun et al., 2003), making the patient is more vulnerable to secondary immunogenic disorders by opportunistic pathogens. Also, as result of deaminating activity of this enzyme, extra amounts of ammonia (hyper-ammoniemia) was released during the course of tumor therapy, causing additional hazardous effects to the kidney and liver, as observed for many of anticancer deaminating enzymes (Balcao et al., 2001). Biochemically, hyperaccumulation of ammonia anticipates on formation of extra amounts of arginine and ornithine, via urea cycle, promoting the polyamines synthesis that indirectly induces tumorgenesis (Pegg, 1988, Gerner and Meyskens, 2004). The immunogenic reactions of bacterial enzyme could be attributed to their structural stereo-conformation during the enzyme posttranslational modifications, prokaryotic nature, making distinct epitopes immunogenic sites on the surface of the enzyme as assumed from the phylogenetic analysis of their amino acids (ElSayed, 2010). Depending on database, the structural amino acid identity of Arabidopsis thaliana L-methioninase was similar to that of Pseudomonas putida by less than $25 \%$, suggesting the differences on the surface amino acid constitution (El-Sayed, 2010). Accordingly, L-methioninase was classified structurally in two forms; First, PseudomonasTrichomonas group that contain six subgroups namely; Pseudomonas, Bacillus, Brevibacterium, Trichomonas, Rhizobium and Aeromonas. Second; Arabidopsis group which represented by A. thaliana. Interestingly, the similarity of amino acid composition of L-methioninase is closely related to the systematic morphological and physiological position of the organism. Actually, the amino acid composition of the fungal L-methioninase open reading frame, nor crystallographic studies was not studied. Therefore, regarding to the therapeutic implications of currently applied L-methioninase, the searching for a novel enzyme with less immunogenic activity and high therapeutic potentiality or modifications of the currently used enzymes is a challenge for many biotechnologists.

\section{Different approaches to increase the therapeutic potentiality of I- methioninase}

\subsection{PEGylation of L-methioninase}

Immobilization of the therapeutic enzymes on polyethylene glycol (PEG), PEGylation, is one of the most successful strategies that originated in 1970 (Abuchowski et al., 1977). PEGylation of albumin and catalase was the milestone for the development and globalization of this technique, as efficient method for modification of the structural and immunogenic identities of proteins (Abuchowski et al., 1977). Polyethylene glycol is a neutral, water soluble, hydrophilic polyether with less immunogenicity that ensure various pharmacological properties as increasing half-life time, reducing the kidney clearance, protecting protein from proteolysis by via steric hindrance, reduce the immunogenicity of protein, increasing the solubility of target therapeutic agent (Reddy, 2000, Veronese and Pasut, 2005, Fee and Van Alsteine, 2004, Pasut and Veronese, 2009). The therapeutic behavior of PEGylated-enzyme was illustrated (Fig. 4). PEGylated-enzyme have a reduced 
kidney excretion, with more plasma half-life time for the increasing of its molecular size (hydrodynamic radii), masking the sensitive amino to chemical modification, shielding the critical surface active sites from proteolysis, antibodies recognition and/or interaction with inhibitors (Harris, 1991; Zalipsky, 1995; Harris et al., 2001; Veronese and Harris, 2002), comparing to free enzyme. Also, PEGylation reduce the protein opsonization and adhesion to liposomes, microparticles (Fee and Van Alstine, 2004). Currently, PEGylation become a well developed technique for formulations of biopharmaceuticals for improving their solubility, bioavailability and decreasing their immunogenic properties as approved by FDA organization (Pasut et al., 2007). PEGylated forms of therapeutic enzymes as Escherichia coli asparaginase (Abuchowski et al., 1979), arginine deiminase (Izzo et al., 2007), Bacillus subtilis arginase (Cheng et al., 2005), Aspergillus flavus uricase (Bayol et al., 2002) displays affordable therapeutic potentialities comparing to corresponding free enzymes, as declared by FDA.

PEGylation of Pseudomonas putida L-methioninase was extensively studied (Tan et al., 1998 and Sun et al., 2003). The half-life time of PEG-L-methioninase was increased to $160 \mathrm{~min}$, comparing to $80 \mathrm{~min}$ to the unmodified enzyme. However, the activity of L-methioninase was relatively not inhibited by PEGylation as appeared from the $\mathrm{IC}_{50}$ values against human lung and kidney tumors (Tan et al., 1998). In addition, PEGylation enhance the half-life times of the recombinant L-methioninase by about 20 fold and rate of serum methionine depletion by about 12 fold (Sun et al., 2003). Apparently, the degree of enzyme PEGylation usually correlate with the decreasing on enzyme immunogenicity and prolonged half-life time, in vivo. For example, the in vivo half-life times was increased from 12, 18 to $38 \mathrm{~h}$ upon degree of PEGylation of L-methioninase by 30/1,60/1 and 120/1 molar ratios, respectively, comparing to the $2 \mathrm{~h}$ for the naked L-methioninase. PEGylation decreases the titer of IgG by about 10 and 10000 fold for PEG-rMETase 30/1 and 120/1 molar ratios, degree of PEGylation comparing to free enzyme (Sun et al., 2003). Also, administration of external pyridoxal phosphate remarkably confers the half-life times and activity of PEG-rMETase. The significant decrease on the enzyme immunogenicity was appeared from the titer of antiPEG-METase as significantly reduced comparing to the native enzyme. As could be deduced, the more degree of PEGylation, the more masking of the superficial antigenic, epitopes, sites of the enzyme (Sun et al., 2003, Yang et al., 2004). The decrease on the activities of native of PEG-L-methioninase in vivo may attributed to dissociation of PLP Coenzyme (Yang et al., 2004), that being confirmed by our results in vitro (El-Sayed, 2011). However, L-methioninase and co-enzyme being easily re-associate upon external supplementation of pyridoxal phosphate as appeared by A420/280 ratio parallel to spectroscopic analysis for determination of the enzyme activity (El-Sayed, 2011). Thus, the combination of PEG-L-methioninase and pyridoxal phosphate infusion, or periodical supplementation of PLP by external osmotic pump, may exhibit a new strategy for prolonging the half-life time, for maximum enzyme therapeutic exploitation. LMethioninase displays two absorption maxima at $280 \mathrm{~nm}$, as aromatic amino acids containing protein, and at $420 \mathrm{~nm}$ due to the internal aldimine linkage of the aldhyde group of pyridoxal phosphate and $\varepsilon$-amino group of lysine N-terminal domain of PLP-enzyme. The absorption spectra of bacterial and fungal L-methioninase (Tanaka et al., 1977, Johnston et al., 1979, El-Sayed, 2011) are typically to other pyridoxal-dependent enzymes (Bertoldi et al., 2002; Saha et al., 2009). The pyridoxal phosphate co-enzyme was dissociate from the apoenzyme by incubation with $10 \mathrm{mM}$ hydroxylamine, giving one peak at $280 \mathrm{~nm}$, with disappearance of the $420 \mathrm{~nm}$ peak due to the dissociation of the PLP and hydrolysis of the internal aldimine bond. To evaluate the structural reconstitution potentiality of fungal L- 
methioninase, different doses of PLP was supplemented to the apo-enzyme, the structural and catalytical efficiency was monitored. The ratio of A280/420 was decreased from 4.01 to 1.7 , upon addition of pyridoxal phosphate $(0.2 \mathrm{mM})$ to the apo-enzyme, indicating the full reconstitution of the active holo-enzyme (El-Sayed, 2011) (Fig.5). Johnston et al. (1979) reported that upon freezing and thawing the ratio of A280/420 of Pseudomonas ovalis Lmethioninase was increased from 3.90 to 4.7 , due to the dissociation of pyridoxal phosphate. $P$. ovalis L-methioninase lacks the ability to restore its original activity by dialysis against pyridoxal phosphate (Johnston et al., 1979), while that of Trichomonas vaginalis enzyme restore more than $90 \%$ of its activity by $0.1 \mathrm{mM}$ PLP (Lockwood and Coombs, 1991). However, A. flavipes L-methioninase has the ability to reconstitute its fully structural catalytic state upon addition of pyridoxal phosphate $(0.2 \mathrm{mM})$, similarly to cystathionine $\gamma$ lyase (Zhu et al., 2008).

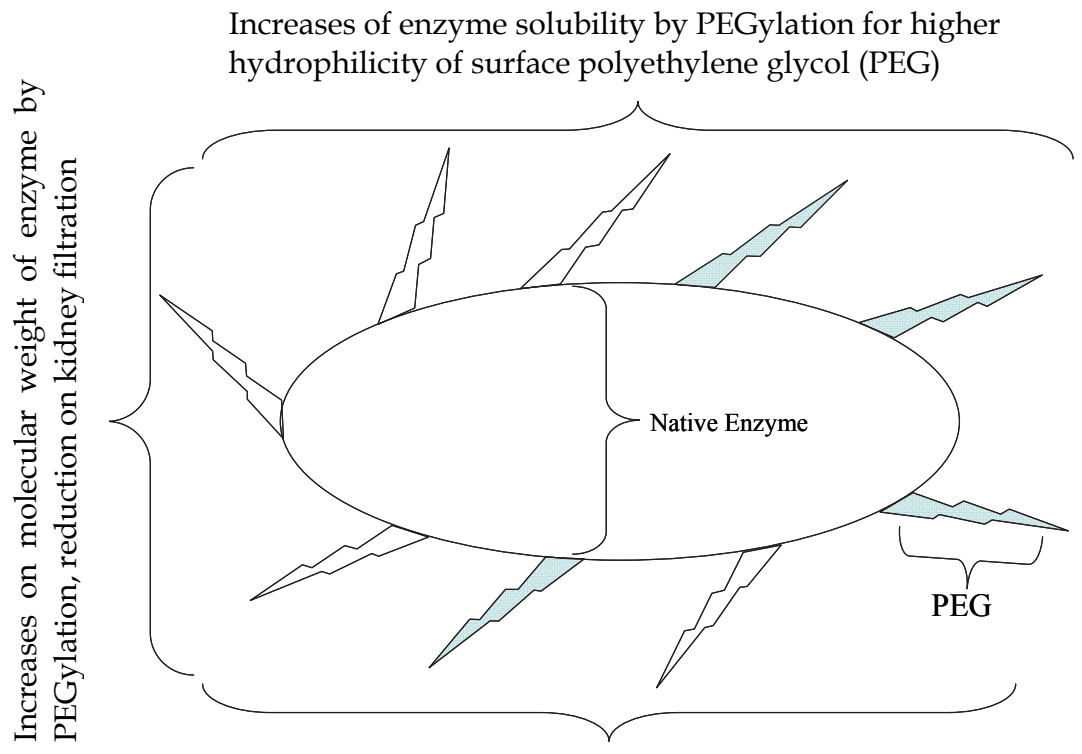

Shielding the antigenic surface sites from antibodies, reducing their accessibility from proteolytic enzymes

Fig. 4. Prospective of enzyme PEGylation 


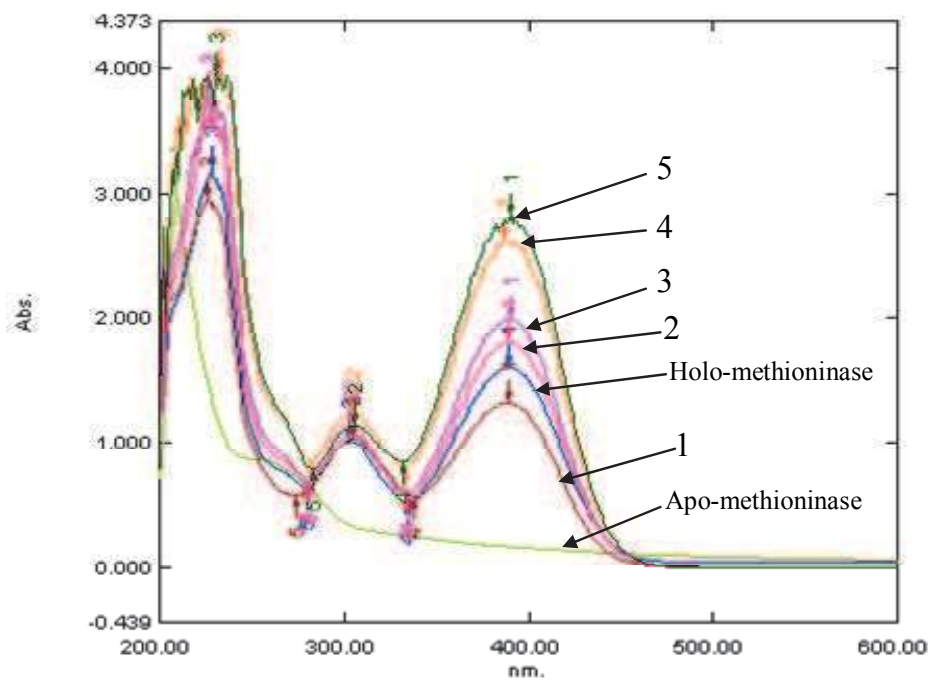

Fig. 5. Absorption spectra of holo and apo-methioninase from A. flavipes (El-Sayed, 2011). Apo-methioninase obtained by preincubation of the holo-enzyme $(2.2 \mathrm{mg} / \mathrm{ml})$ in potassium phosphate buffer ( $\mathrm{pH} 7.8$ ) with $10 \mathrm{mM}$ hydroxylamine. Reconstruction of the holo-enzyme by incubation of the apo-methioninase with $0.04 \mathrm{mM}$ PLP (1), 0.08 mM PLP (2), 0.1 mM PLP (3), $0.15 \mathrm{mM}$ PLP (4) and 0.2 $\mathrm{mM}$ PLP (5).

\section{Combination between L-methioninase and chemotherapeutic agents}

Synergism between L-methioninase and chemotherapeutic agents present a new strategy against various types of tumors (Yoshioka et al., 1998). Biochemically, starvation of the tumor cells to L-methionine, by action of L-methioninase or L-methionine depleted diets usually make the tumor cells more vulnerable to any biochemical modulator as reviewed by El-Sayed (2010). Methionine starvation and simultaneous phase-specific chemotherapeutic agent is an overall concept for all therapeutic strategies. 5-Fluorouracil, common biochemical modulator, an analogue to thiamine, that competitively bind to thymidylate synthetase, causing prompted suppression to DNA synthesis of tumor cells (Poirson-Bichat et al., 1997). The sensitivity of Lewis lung carcinoma to L-methioninase was increased by about 4.5 fold by addition of 5-fluorouracil (Hoshiya et al., 1997, Tan et al., 1998, Yoshioka et al., 1998). Similarly, doxorubicin as intercalating agent blocks the cell cycle, greatly improves the activity of L-methioninase against human lung carcinoma H460 (Gupta et al., 2003). Ethionine, as methionine analogue, in combination with methionine starved diets display a potent activity against human colon and lung tumors, that attributed to inhibition of methyltransferase leading to DNA, RNA, protein hypomethylation (Razin and Riggs, 1980 and Poirson-Bichat et al., 2000). Also, methionine free diets potentiality against human prostate and glioma was strongly augmented by supplementation of ethionine that attributed to reduction of ATP pool and glutathione synthesis (Guo et al., 1996, PoirsonBichat et al., 1997). Also, methionine deprivation induce the hypomethylation reactions that lowers the glutathione and alters folate metabolism causing selective arresting to the cell cycle in the late of S/G2 phase, strongly modulate the efficiency of Cisplatin against human 
breast carcinoma (Hoshiya et al., 1996). However, continuous starvation of human serum to methionine may exert hazardous implications to liver (Kokkinakis, 2006). Biochemically, combination of methioninase with various therapeutic agents, for methionine starvation, as doxorubicin (Stern et al., 1984), 5-fluoruracil, mitomycin C (Goseki et al., 1992), nitrosoureas (Kokkinakis et al., 2001) and BCNU (Kokkinakis et al. 1997), display a new approach for treatment of methionine dependent tumor cells.

\section{L-Methioninase gene therapy and selenomethionine as prodrugs}

Introduction of the L-methioninase encoding genes to tumor cells with regulating their expression one of the recent challenges for treating of tumor cells as reviewed by El-Sayed (2010). Transduction of bacterial L-methioninase gene via developed adenoviral vector, with exogenous L-methioninase, display a powerful activity towards human ovarian cancer cells (Miki et al., 2000a). The potentiality of gene therapy for methionine dependent tumors based on deprivation of the tumor cells from the intrinsic L-methionine, so this technique significantly intensified by combination with external L-methioninase, to remove the serum L-methionine. A plausible anti-proliferative activity towards human lung cancer by transduction of $P$. putida L-methioninase gene via retroviral vectors, in combination with methioninase treatment, was observed (Miki et al., 2000b). Transduction of P. putida Lmethioninase gene to human lung carcinoma using retroviral victors and their therapeutic implications were extensively studied by Tan et al., 1997, Miki et al., 2000a,b, 2001). In contrary to hypomethylation by extrinsic starvation of L-methionine, introduction of p53 genes using retroviral, adenoviral, lipid based delivery, displays an efficient strategy against various types of p53 regulated tumors (Miki et al., 2001). Unfortunately, different genetic therapeutical trials is rarely occurred without signs of biochemical implications as low clinical efficiency and lethal toxicity (Fox, 1999), due to the production of some anti-apoptic mitochondrial proteins that counteract the introduced methioninase gene (Yamamoto et al., 2003). Mitochondrial protein (Bc1-2) is the common released anti-apoptotic proteins that hinder the release of mitochondrial cytochrome $c$ to cytosol thus counteracting different gene therapeutic approaches (Hamel et al., 1996, Carsten et al., 2000). Additionally, the low transduction efficiency by retroviral L-methioninase gene hinders their therapeutic potentiality. Recently, a novel strategy for reduction the clinical hazardous and augmentation of the pharmacokinetic impact of this enzyme via combination of gene therapy and selenomethionine as prodrugs as reported by Miki et al. (2001) and Yamamoto et al. (2003). In addition to intracellular and extracellular depletion of L-methionine, introduction of selenomethionine, as non-toxic prodrug, plausibly maximize the therapeutic potentiality of this approach, against tumor cells. Selenomethionine, methionine analogue, is a prodrug that under $\gamma$-elimination forming a powerful toxic methylselenol, a-ketobutyrate and ammonia (El-Sayed, 2010). Subsequently methylselenol catalyzes thiols oxidation generating reactive oxygen species as superoxide causing mitochondrial swelling, releasing cytochrome $c$, activation of caspase inducing prompt cell apoptosis (Green and Reed, 1998, Miki et al., 2001, Yamamoto et al., 2003). Methylselenol released from L-methioninase gene transduced tumor cell can easily adsorbed by surrounding cells, bystander effect, generating the same toxicity on mitochondrial system (Miki et al., 2001) as reviewed by El-Sayed (2010). Unlike the sensitivity of tumor cells to methylselenol, the normal human cells were not being affected for their lack to L-methioninase (Hoffman, 1984). The sensitivity of tumor cells to transduction by adenovirus methioninase gene and selenomethionine as prodrug was increased by 1000 fold (Miki et al., 2000a) comparing to only gene transduced cells. 
Currently, in a revolution of biotechnology in the fight against cancer, directing of the enzyme via antibodies to the target tumor cells for removal of extracellular methionine in addition to transduced enzyme gene and selenomethionine as prodrug is the promising strategy against various types of tumors (Napier et al., 2000, Zhao et al., 2006). This novel approach referred as Antibody Directed Enzyme Prodrug Therapy (ADEPT) that is reliable strategy to avoid the systemic clinical and therapeutical limitations of the traditional approaches (Sharma et al., 2005). However, several trials for construction of enzyme antibodies models (Bagshawe, 1987, Stener and Springer, 2001, Bagshawe et al., 2004) were experimented. However, the design of enzyme-antibody without interactions on the enzyme catalytic sites and specific to receptors on the surface of tumor cells is main challenge by biotechnologists, for approving this strategy. After transduction of L-methioninase gene to the target tumor cells, the enzyme-antibody was introduced to the human plasma followed by injection of selenomethionine as planned by several trials as reviewed by El-Sayed (2010).

\section{Exploitation of L-methioninase as a target for antimicrobial drugs}

Uniqueness distribution of L-methioninase as intracellular enzyme among all microbial pathogens, but not humans makes this enzyme is a novel target for antibacterial, antifungal and anti-protozoal therapies (Ali and Nozaki, 2007, Sato and Nozaki, 2009). Trifluoromethionine (TFM), a fluorinated methionine that undergoes $\beta$, $\gamma$-elimination forming trifluoro-methanethiol $\left(\mathrm{CF}_{3} \mathrm{SH}\right)$ that converted to carbonothionic difluoride which subsequently interacted with primary amino groups of the enzymes lysine moieties, causing cellular toxicities (Alston and Bright, 1983, Sato et al., 2008). TFM was reported as a potent antibacterial agent towards the growth of Mycobacterium smegmatis, M. phlei and Candida lipolytica (Zygmunt and Tavormina, 1966, Sato and Nozaki, 2009), P. gingivalis, F. nucleatum (Yoshimura et al., 2002) and antiprotozoal agent Entaemoba histolytica (Coombs and Mottram, 2001). Also, TFM is highly effective against many anaerobic bacteria as Clostridium botulinum (botulism), C. difficile (colitis), Porphyromonas sp (tooth decay) and Bacteroides sp (intra-abdominal infections) (Finegold and Wexler, 1996). Methionine and TFM was activated by methionine adenosyltransferase for further metabolic biochemical pathways. Mammalian cystathionine $\gamma$-lyase doesn't affected by the presence of TFM (Alston and Bright, 1983). Myrsinoic acid B and terpeno-benzoic acid extracted from Myrisine seguinii, were reported as potent anti-methioninase, anti-inflammatory and anti-edema agents (Hirota et al., 2002, Ito et al., 2008). Myrsinoic acid exhibits a significant activities against $F$. nucleatum $\left(\mathrm{IC}_{50} 0.39 \mu \mathrm{m}\right)$, T. denticoal $\left(\mathrm{IC}_{50} 30.3 \mu \mathrm{M}\right)$ and P. gingivalis $\left(\mathrm{IC}_{50} 82.4 \mu \mathrm{M}\right)$, it used as powerful anti-malodor and periodontal disease (Sato and Nozaki, 2009). Propargylglycine as cysteine analogues, was widely reported as suicide L-methioninase catalytic inhibitor, in vitro (El-Sayed, 2011), with relatively low deleterious effect on whole growth of amoebic trophozites, E. histolytica (Ali and Nozaki, 2007), suggesting alternative shunt for sulfur amino acid metabolism other than L-methioninase (Coombs and Mottram, 2001). Thus, for unique distribution of L-methioninase as intracellular enzyme among pathogenic microbes, the searching for various inhibitors with reliable specificity to this enzyme will be a justifiable new trend of antimicrobials agents.

\section{Pyridoxal phosphate-dependent enzymes deficiency and cardiovascular diseases}

Biochemically, transsulfuration and reverse-transsulfuration pathways are the pivotal mechanisms for proper accumulation of homocysteine and cystathionine. As shown in Fig. 
(3), these pathways are controlled by four PLP-dependent enzymes namely; cystathionine $\beta$, $\gamma$-synthases and cystathionine $\gamma, \beta$-lyases. Inactivation of transsulfuration enzymes as cystathionine $\beta$-synthase causes hyperaccumulation of homocysteine (homocysteinuria) that is a visual risk of cardiovascular diseases, damage to vascular endothelia, increases to the risk of abnormal blood clots and skeletal abnormalities (De Bree et al., 2002; Wald et al., 2002) and Alzheimer's disease (Morris, 2003). Also, homocysteinuria usually associated with intellectual disability, seizures and megaloblastic anemia (Mudd et al., 1985). Practically, it commonly reported as genetic or metabolic disorders that affect on the metabolism of protein, generally one to 200,000 babies are born with genetic disorders. Homocysteinuria is a biochemically disorder due to the deficiency of cystathionine $\beta$-synthase, owing to the genetically inborn error of the transsulfuration pathway that increases the homocysteine and methionine, with crucial decreasing to the cysteine pool (Mudd et al., 1985). The major clinical implication of homocysteinuria includes mental retardation, dislocation of the optic lenses, skeletal abnormalities (Schuh et al., 1984). Dietary therapy relying of deprivation of methionine and supplementation of cysteine display a reliable positive result in delaying the clinical manifestations (Pullon, 1980). However, supplementation of cystathionine $\beta$ synthase was the potent relevant therapy for dramatically conversion of homocysteine to cystathionine (Zhu et al., 2008). Since cystathionine $\beta$-synthase is a PLP-dependent enzyme and the rapid dissociation of PLP as coenzyme from the apoenzyme is a common structural and catalytic criteria (El-Sayed, 2010, 2011), external supplementation of pyridoxal phosphate, vitamin B6 gave a plausible results for decreasing the amount of homocysteine, assuming the reassociation of apo-cystathionine $\beta$-synthase forming the holo-enzyme (Barber and Spaeth, 1967). Moreover, the deficiency of cystathionine $\gamma$-lyase results in accumulation of cystathionine (Cystathioninuria) that usually accompanied with diabetes, Down's syndrome, neuroblastoma (Wang and Hegele, 2003) as reviewed by Zhu et al. (2008).

\section{Industrial application of I-methioninase: methanethiol production}

Methanethiol has enormous biotechnological applications such as key gradient in gas odorants, jet fuel additives and coke formation in steel mill furnaces (Welirnan 1966). Recently, it is used for preparation of modified gold biosensors, manufacturing of plastics and pesticides (Jin et al. 2005, Nakamura et al. 2006). Also, it is the precursor for dimethyltrisulfide, S-methylthio-esters and 2,4-dithiapentane production (Chin and Lindsay 1994, Amarita et al. 2004), as presulfiding, hydrocracking catalysts, extracting solvents, manufacturing of ion-exchange resins and as modifier of Nylon fibers (Herschler 1962; Stewart and Lasis 1965) (www.gaylardchemical.com).

Chemically, methanethiol can be synthesized by reaction of methanol with hydrogen sulfide (Scott et al., 1955). The reaction was preceded at $380^{\circ} \mathrm{C}\left(716^{\circ} \mathrm{F}\right)$ in the presence of $\mathrm{K}_{2} \mathrm{MoSO}_{4} / \mathrm{SiO}_{2}$ as catalyst and $2 \mathrm{MPa}$. By chemical methods usually methanethiol accompanied with formaldehyde, requiring more steps for purification, especially with higher solubility of methanethiol in water (Yang et al., 1998). Commercially, the price of methanethiol salt is about eighteen fold higher than L-methionine, also one gram of sodium methanethiolate is 3.6 folds more than one liter of methanol (Sigma-Aldrich Co 2010).

Consequently, the enzymatic method, using L-methioninase seems to be a plausible process for large scale production of methanethiol from the technical and economical point of views. For the high expense of enzyme purification from the microbial cultures, immobilization is a 
promising technique for enzyme stabilization and continuous production of methanethiol (El-Sayed and Shindia, 2011). Among the tested methods, polyacrylamide $(42.2 \%)$, Caalginate $(40.9 \%)$ and chitin $(40.8 \%)$ displaying the highest A. flavipes L-methioninase immobilization efficiency. Chitin-enzyme gave a plausible stability till $4^{\text {th }}$ cycle for production of methanethiol under controlled system. Applying GC and HNMR analysis, methanethiol has identical chemical structure to the standard compound. A new method for continuous production of pure methanethiol using a simple low expense enzymatic method was developed (El-Sayed and Shindia, 2011).

\section{Prospectives for improving the therapeutic potentiality of PLP-dependent enzymes}

Regarding to publications describing the structural and catalytic identities of PLPdependent enzymes and their wide therapeutic and pharmaceutical applications, the immunogenicity and relative instability were the common limitations from pharmacokinetic point of view. Actually, all of these enzymes that receive considerable attention as therapeutic agent were of bacterial sources as reviewed by El-Sayed (2010). However, the crystallographic and biochemical studies for various therapeutic enzymes reveal a reliable distinction on the enzyme conformational structural of surface amino acids and immunogenic sites, from prokaryotes to eukaryotes (Kusakabe et al., 1979). Unlike the extensive studies of bacterial PLP-dependent enzymes, no more publications for biochemical characterization and crystal structures of these enzymes from eukaryotes, in spite of their distinct structural identity from eukaryotes as revealed from amino acid constitution (El-Sayed, 2010). Thus, further biochemical and crystallographic studies to elucidate the catalytic identity and tertiary structure of eukaryotic PLP-enzymes for the maximum therapeutic exploitation of these enzymes need to be resolved. The plausible reassociation of PLP coenzyme with the apo-L-methioninase with full activity, comparing to lower to inability to re-association of the corresponding enzymes from prokaryotes, is an obscure, and their authorization with greatly participates in explanation of their catalytic and immunogenic identities. In addition, immobilization and co-immobilization studies of these enzymes will significantly maximize their biotechnological and therapeutical applications. Regarding to gene therapy, PEGylation and directing of these enzymes to specific tumors via targeting by modified antibodies or nao-particles is the main challenge for our ongoing research.

\section{References}

Abuchowski A., Van ES, T., Palczuk,N.C. and Davis F.F. (1977): Alteration of immunological properties of bovine serum albumin by covalent attachment of polyethylene glycol. J. Biol. Chem. 252: 3578-3581.

Abuchowski A., Van ES T., Palczuk N.R., McCoy J.R. and Davis F.F. (1979): Treatment of L5178Y tumor-bearing BDF1 mice with a non-immunogenic L-glutaminase-Lasparaginase. Cancer Treat. Rep. 63: 1127-1132.

Agrawal N.R., Bukowski R.M., Rybicki L.A, Kurtzberg J., Cohen L.J. and Hussein M.A. (2003): A phase I-II trial of polyethylene glycol-conjugated L-asparaginase in patients with multiple myloma. Cancer 98:94-99 
Alexander F.W., Sandmeier E., Mehta P.K. and Christen P. (1994): Evolutionary relationships among pyridoxal-5-phosphate-dependent enzymes. Regio-specific alpha, beta and gamma families. Eur. J. Biochem. 219: 953-960.

Ali V. and Nozaki T. (2007): Current Therapeutics, Their problems, and sulfur-containing amino acid metabolism as a novel target against infections by Amitochondriate Protozoan parasites. Clinical Microbiology Rev. 20: 164-187.

Alston T.A. and Bright H.J. (1983): Conversion of trifluoromethionine to a cross-linking agent by gamma-cystathionine. Biochem. Pharmacol., 32: 947-950.

Amarita F., Yvon M., Nardi M., Chambellon E., Delettre J. and Bonnarme P. (2004): Identification and functional analysis of the gene encoding methionine- $\gamma$-lyase in Brevibacterium linens. Appl. Environ. Microbiol. 70: 7348-7354.

Anderson ME (1998): Glutathione: an overview of biosynthesis and modulation. Chem. Biol. Interact 112: 1-14.

Bagshawe K.D. (1987): Antibody directed enzyme revive anticancer prodrug concept. Br. J. cancer, 56: 531-532.

Bagshawe K.D., Sharma S.K., Begent R.H.J. (2004): Antibody-directed enzyme prodrug therapy (ADEPT) for cancer. Expert. Opinion Biol. Ther. 4: 1777-1789.

Bahn J.H., Kwon O.S., Joo H.M., Jang S.H., Park J., Hwang I.K., Kang T.C., Won M.H., Kwon H.Y., Kwok F., Kim H.B., Cho S.W. and Choi S.Y. (2002): Production of monoclonal antibodies and immuno histochemical studies of brain pyridoxine-5-phosphate oxidase. Brain Res. 925: 159-168.

Balcao V.M., Mateo C., Fernandez-Lafuente R., Malcata F.X. and Guisan J.M. (2001): Coimmobilization of L-asparaginase and glutamate dehydrogenase onto highly activated supports. Enz. Microbial. Technol. 28: 696-704.

Barber G.W. and Spaeth G.L. (1967): Pyridoxine therapy in homocysteinuria. Lancet 1: 337

Baylin S.B., Herman J.G., Graff J.R., Vertino P.M., Issa J.P. (1998): Alteration in DA methylation: a fundamental aspect of neoplasia. Adv. Cancer Res. 72: 141-196.

Bayol A., Capdevielle J., Malazzi P., Buzy A., Bonnet M.C., Colloc'h N., Mornon J.P., Layaux D. and Ferrara P. (2002): Modification of a reactive cysteine explains differences between rasburicase and uricozyme, a natural Aspergillus flavus uricase. Biotechnol. Appl. Biochem. 36: 21-31.

Bean L.E., Dvorachek W.H., Braun E.L., Erret A., Saenz G.S., Giles M.D., Erner-Washburne M., Nelson M.A. and Nativg D.O. (2001): Analysis of the $p d x-1$ (snz-1/sno-1) region of the Neurospora crassa genome: correlation of pyridoxine-requiring phenotypes with mutations in two structural genes. Genetics 157: 1067-1075.

Beinert H. (2000): Iron-sulfur proteins: ancient structures, still full of surprises. J. Biol. Inorg. Chem. 5: 2-15.

Bertoldi M., Cellini B., Clausen T. and Voltattorni C.B. (2002): Spectroscopic and kinetic analyses reveal the pyridoxal 5-phosphate binding mode and the catalytic features of Treponema denticola. Biochem. 41: 9153-9164

Brewke C. and Leistner E. (2001): Biosynthesis of vitamin B6 and structurally related derivatives. Vitam. Horm. 61: 121-155.

Buchman A.L., Lyaer K., Fryer, J. (2006): Parenteral nutrition-associated liver disease and the role for isolated intestine and intestine/liver transplantation. Hepatology 43: 9-19.

Burkhard P., Rao G.S., Hohenester E., Schnackerz K., Cook P.F. and Jansonius J.N. (1998): Three-dimensional structure of O-acetylserine sulfhydrolase from Salmonella typhimurium. J. Mol. Biol. 283: 121-133. 
Carsten F., Christph S., Barbara H. et al., (2000): Bcl-2 expression in high-grade human glioma: Clinical and exprimental study. J. Neurooncol. 48: 207-216.

Casasnovas R., Salva A., Frau J., Donoso J. and Munoz F. (2009): Therotical study on the distribution of atomic charges in the Schiff base of 3-hydroxypyridine-4-aldehyde and alanine. The effect of the protonation state of the pyridine and imine nitrogen atoms. Chemical Physics. 355: 149-156.

Cellarier E., Durando X., Vasson M.P., Farges M.C., Demiden A., Maurizis J.C., Madelmont J.C., Chollet P. (2003): Methionine dependency and cancer treatment. Cancer Treat Rev 29: 489-499

Cheng P.N., Leung Y.C., Lo W.H., Tsui S.M. and Lam K.C. (2005): Remission of hepatocellular carcinoma with arginine depletion induced by systemic release of endogenous hepatic arginase due to trans-heptic arterial embolisation, augmented by high-dose insulin: arginase as a potential drug candidate for hepatocellular carcinoma. Cancer Lett. 224: 67-80.

Chin H.W. and Lindsay R.C. (1994): Ascorbate and transition-metal mediation of methanethiol oxidation to dimethyldisulfide and dimethyltrisulfide. Food Chem. 49: 387-392..

Choi S.W. and Mason J.B. (2002): Folate status: effects on pathways of colorectal carcinogenesis: J. Nut. 132: 2413-2418

Choi J.D., Bowers-Komoro M., Davis D.M., Edmondson D.E., McCormick D.B. (1983): Kinetic properties of pyridoxamine (pyridoxine)-5-phosphate oxidase from rabbit liver. J. Biol. Chem. 258: 840-845.

Coffino P. (2000): Polyamines in spermigenesis: Not now, darling. Proc. Natl. Acad Sci. USA. 97: 4421-4423.

Coombs G.H. and Mottram J.C. (2001): Trifluoromethionine, a prodrug designed against methionine gamma-lyase-containing pathogens, has efficacy in vitro and in vivo against Trichomonas vaginalis. Antimicrobial Agents Chemotherapy 45: 1743-1745.

Cooper A.J.L. (1983): Biochemistry of sulfur-containing amino acids. Annual Rev. Biochem 52: $187-222$

Davidson N.E., Hahm H.A., McCloskey D.E., Woster P.M., Casero Jr R.A. (1999): Clinical aspects of cell death in breast cancer: the polyamine pathway as a new target for treatment. Endocr. Relat. Cancer 6: 69-73.

Davis C.D. and Uthus E.O. (2004): DNA methylation, cancer susceptibility and nutrient interactions. Exp. Biol. Med. 229: 988-995.

De Bree A., Verscuren W.M., Kromhout D., Kluijtmans L.A. and Blom H.J. (2002): Homocysteine determinates and the evidence to what extent homocysteine determines the risk of coronary heart disease. Pharmacol. Rev. 54: 599-618.

Denesyuk A.I., Denessiouk K.A., Korpela T. and Johnson M.S. (2002): Functional attributes of the phosphate group binding cup of pyridoxal phosphate-dependent enzymes. J. Mol. Biol. 316: 155-172.

Denesyuk A.I., Denessiouk K.A., Korpela T., and Johnson M.S. (2003): Phosphate group binding cup of PLP-dependent and non-PLP-dependent enzymes: Leitmotif and variations. Biochimica et Biophysica Acta, 1647: 234-238.

Dominy J.E. and Stipanuk M.H. (2004): New roles for cysteine and transsulfuration enzymes: production of $\mathrm{H} 2 \mathrm{~S}$, a neuromodulator and smooth muscle relaxant. Nutr. Rev., 62: 348-53. 
Ehrenshaft M. and Daub M.E. (2001): Isolation of PDX2, a second novel gene in the pyridoxine biosynthesis pathway of eukaryotes, archaebacteria, and a subset of eubacteria. J. Bacterial. 183: 3383-3390.

El-Sayed A.S.A. (2009): L-Methioninase production by Aspergillus flavipes: under solid state fermentation. J. Basic Microbiol. 49: 331-341.

El-Sayed A.S.A. (2010): Microbial L-Methioninase, molecular characterization, and therapeutic applications. Appl. Microbiol. Biotechnol. 86: 445-467.

El-Sayed A.S.A. (2011): Purification and characterization of new L-methioninase from solid cultures of Aspergillus flavipes. J. Microbiol. 49: 130-40.

El-Sayed A.S.A. and Shindia A.A. (2011): Characterization and immobilization of purified Aspergillus flavipes 1-methioninase: continuous production of methanethiol. J. Appl. Microbiol. DOI: 10.1111/j.1365-2672.2011.05027.x.

El-Sayed A.S.A., Fujimoto S., Yamada C. and Suzuki H. (2010): Enzymatic synthesis of $\gamma$ glutamylglutamine, a stable glutamine analogue, by $\gamma$-glutamyl-traspeptidase from Escherichia coli K-12. Biotechnol. Letter 32: 1877-1881.

Fee C.J. and Van Alsteine J.M. (2004): Prediction of the viscosity radius and the size exclusion chromatography behavior of PEGylated proteins. Bioconjug. Chem. 15: 1304-1313.

Finegold S.M. and Wexler H.M. (1996): Present studies of therapy for anaerobic infections. Clinic. Infect. Dis. 23: S9-S14.

Fiskerstrand T., Christensen B., Tysnes O.B., Ueland P.M. and Refusm H. (1994): Development and reversion of methionine dependence in a human glioma cell line: relation to homocysteine remethylation and cobalamin status. Cancer Res. 54: 48994906.

Fox J.L. (1999): Gene Therapy safety issues come to fore. Nature Biotechnology 17: 1153

Gadalla M.M. and Snyder S.H. (2010): Hydrogen sulfide as a gasotransmitter. J. Neurochem. 113: 14-26.

Gallagher D.T. Gilliland G.L., Xiao G., Zondlo J., Fisher K., Chinchilla D. and Eisenstein E. (1998): Structure and control of pyridoxal phosphate dependent allosteric threonine deaminase. Structure 6: 465-475.

Galperin M.Y. and Koonin E.V. (1997): Sequence analysis of an exceptionally conserved operon suggests enzymes for a new link between Histidine and purine biosynthesis. Mol. Micrbiol. 24: 443-445.

Gerner E.W. and Meyskens Jr., F.L. (2004): Polyamines and cancer: Old molecules, new understanding. Nature Rev. Cancer 4: 781-792.

Gilmour S.K. (2007): Polyamines and nonmelanoma skin cancer. Toxicol. Appl. Pharmacol. 224: 249-256.

Goseki N., Yamazaki S., Endo M., Onodera T., Kosaki G., Hibino Y., Kuwahata T. (1992): Antitumor effect of methionine-depleting total parenteral nutrition with doxorubicin administration on Yoshida sarcoma-bearing rats. Cancer 69: 1865-1872.

Green D.R., and Reed J.C. (1998): Mitochondria and apoptosis. Science 281: 1309-1312.

Grishin N.V., Phillips M.A. and Goldsmith E.J. (1995): Modeling of the spatial structure of eukaryotic ornithine decarboxylase. Protein Sci. 4: 1291-1304.

Guo H., Lishko V.K., Herrera H., Groce A., Kubota T. and Hoffman R.M. (1993): Therapeutic tumor-specific cell cycle block induced by methionine starvation in vivo. Cancer Res. 53: 5676-5679. 
Guo H., Tan Y., Kubota T., Moossa, A.R. and Hoffman, R.M. (1996): Methionine depletion modulates the antitumor and antimetastatic efficiency of ethionine. Anticancer Res., 16: 2719-2723.

Gupta A., Miki K., Xu M., Yamamoto N., Mossa A.R., Hoffman R.M. (2003): Combination efficiency of doxorubicin and adenoviral methioninase gene therapy with prodrug selenomethionine. Anticancer Res. 23: 1181-1188

Hamel W., Magnelli L., Chiarugi V.P. and Israel M.A. (1996): Herpes simplex virus thymidine kinase/ ganciclovir-mediated apoptosis death of bystander cells. Cancer Res. 56: 2697-2702.

Hansen J., Muldbjerg M., Cherest H. and Surdin-Kerjan Y. (1997): Siroheme biosynthesis in Saccharomyces cerevisiae requires the products of both MET1 and MET8 gene. FEBS Lett. 401: 20-24.

Harris J.M., Martin N.E. and Modi M. (2001): PEGylation: a novel process for modifying pharmacokinetics. Clin. Pharmacokinetic. 40: 539-551.

Harris M.J. (1991): Poly (Ethylene glycol) Chemistry: Biotechnical and biomedical Applications. Plenum Press, New York.

Herschler R.J.U.S. (1962) Patent 3,023, 074, Feb. 27.

Heyl D.L., Harris E. and Folkers K. (1951): Phosphates of vitamin B6 group I. The structure of Co-decarboxylase. J. American Chemical Society. 73: 3430-3433.

Hirota M., Miyazaki S., Minakuchi T., Takagi T. and Shibata H. (2002): Myrsinoic acids B, C and F, anti-inflammatory compounds from Myrsine seguinii. Biosci. Biotechnol. Biochem. 66: 655-659.

Hoet P.H. and Nemery B. (2000): Polyamines in the lung: polyamine uptake and polyaminelinked pathological or toxicological conditions. Cell Mol. Physiol. 278: 417-433.

Hoffman R.M. (1985): Altered methionine metabolism and transmethylatin in cancer. Anticancer Res. 5: 1-30

Hoffman R.M. (1984): Altered methionine metabolism, DNA methylation, and oncogene expression in carcinogenesis: A review and synthesis. Biochem. Biophys Acta 738: 49-87.

Hoffman R.M. and Erbe R.W. (1976): High in vivo rate of methionine biosynthesis in transformed human and malignant rat cells auxotrophic for methionine. Proc. Natl. Acad .Sci. USA 73: 1523-1527.

Hoshiya Y., Kubota T., Inada T., Kitajima M. and Hoffman R.M. (1997): Methioninedepletion modulates the efficiency of 5-fluorouracil in human gastric cancer in nude mice. Anticancer Res. 17: 4371-4375.

$\mathrm{Hu}$ J. and Cheung N.K. (2009): Methionine depletion with recombinant methioninase: in vitro and in vivo efficacy against neuroblastoma and its synergism with chemotherapeutic drugs. Int. J. Cancer. 124: 1700-1706.

Hult K. and Berglund P. (2007): Enzyme Promiscuity: Mechanism and applications. TRENDS in Biotechnol. 25: 231-238.

Hyde C.C., Ahmed S.A., Padlan E.A., Miles E.W. and davis D.R. (1988): Three-dimensional structure of the tryptophan synthase alpha 2 bet 2 multi-enzyme complex from Salmonella typhimurium. J. Biol. Chem. 263: 17857-17871.

Igarashi K., Sakamoto I., Goto N., Kashiwangi K., Honma R. and Hirose S. (1982): Interaction between polyamines and nucleic acids or phospholipids. Arch. Biochem. Biophys. 219: 438-443. 
Ito S., Narise A. and Shimura S. (2008): Identification of a methioninase inhibitor, myrsinoic acid B, from Myrsine seguinii Lev., and its inhibitor activities. Biosci. Biotechnol. Biochem. 72: 2411-2414.

Izzo F., Montella A.P., Orlando A.P. Nasti G. Beneduca G. and Castello G. (2007): PEGylated arginine deiminase lowers hepatitis $C$ viral titers and inhibits nitric oxide synthesis. J. Gastroenterol. Hepatol. 22: 86-91.

Jansonius J.N. (1998): Structure, evolution and action of vitamin B6-dependent enzymes. Current Opinion Structure Biol. 8: 759-769.

Jin B., Ding S., Kametani K. and Nakamura T. (2005): The preparation and electrochemical behavior of density-controlled gold nano-particles self assembled interface. Chem Lett 34: 302-303.

John R.A.(1995): Pyridoxal phosphate-dependent enzymes. Biochim. Biophys Acta. 1248: 8196.

Johnson L.N., Acharya K.R., Jorrdan M. D. and McLaughlin P.J. (1990): Refined Crystals structure of the phosphorylase-heptulose 2-phosphate oligosaccharide-AMP complex. J. Mol. Biol. 211: 645-661.

Johnston M., Jankowski D., Marcotte P., Tanaka H., Esaki N., Soda K. and Walsh C. (1979): Suicide inactivation of bacterial cystathionine $\gamma$-synthetase and methionine $\gamma$-lyase during processing of L-propargylglycine. Biochemistry 18: 4690-4701.

Jones P.A. and Baylin S.B. (2002): The fundamental role of epigenetic events in cancer. Nat Rev Genetic 3: 415-428.

Kenyon S.H., Waterfield C.J., Timbrell J.A. and Nicolaou A. (2002): Methionine synthase activity and sulphur amino acid levels in the rat liver tumor cells HTC and Phi-1. Biochem Pharmacol. 63: 381-391.

Kern A.D., Oliveira M.A. Coffino P. and Hackert M.L. (1999): Structure of mammalian ornithine deacrboxylase at $1.6^{\circ} \mathrm{A}$ resolution: Sterochemical implications of PLPdependent amino acid decarboxylase. Structure 7: 567-581.

Kessler D. (2006): Enzymatic activation of sulfur for incorporation into biomolecules in prokaryotes. FEMS Microbiol. Rev. 30: 825-840.

Kimura H. (2010): Hydrogen sulfide: from brain to gut. Antioxid. Redox Sigal. 12: 1111-1123.

Klimberg V.S. and McClellan J.L. (1996): Glutamine, Cancer and its therapy. Am. J. Surg. 172: 418-424.

Khalaf S.A. and El-Sayed A.S.A. (2009): L-Methioninase production by filamentous fungi: IScreening and optimization under submerged conditions. Curr. Microbiol. 58: 219226.

Kokkinakis D.M. (2006): Methionine-stress: a pleiotropic approach in enhancing the efficacy of chemotherapy. Cancer Lett. 233: 195-207.

Kokkinakis, D.M., Hoffman, R.M., Frenkel, E.P., Wick, J.B., Han, Q., Xu, M., Tan, Y. and Schold, S.C. (2001): Synergy between xenografts in athymic mice. Cancer Res. 61: 4017-4023.

Kreis W. and Goodenow M. (1978): Methionine requirement ad replacement by homocysteine in tissue cultures of selected rodent and human malignant and normal cells. Cancer Res 38: 2259-2260.

Kudou D., Misaki S., Yamashita M., Tamura T., Takakura T., Yoshioka T., Yagi S., Hoffman R.M., Takimoto A., Esaki N. and Inagaki K. (2007): Structure of the antitumor enzyme L-methionine $\gamma$-lyase from Pseudomonas putida at $1.8^{\circ} \mathrm{A}$ resolution. J. Biochem. 141:535-544 
Kusakabe H., Kodama K., Machida H., Midorikawa Y., Kuninaka A., Misono H. and Soda K. (1979): Occurrence of a novel enzyme, L-lysine oxidase with antitumor activity in culture extract of Trichoderma viride. Agric. Biol. Chem. 43: 337-343.

Le Magueres, P., Im, H., Ebalunode, J., Strych, U., Benedik, M.J., Briggs, J.M., Hohn, H. and Krause K.L. (2005): The $1.9 \AA$ crystal structure of alanine racemase from Mycobacterium tuberculosis contains a conserved entryway into the active site. Biochemistry 44: 1471-1481.

Lishko V.K., Lishko O.V. and Hoffman R.M. (1993): The preparation of endotoxin-free Lmethionine-a-deamino- $\gamma$-mercaptomethane-lyase (L-Methioninase) from Pseudomonas putida. Protein Expr. Purif. 4: 529-533.

Liteplo R.G., Hipwell S.E., Rosenblatt D.S., Sillaots S. and Lue-Shing H. (1991): Changes in cobalamine metabolism are associated with the altered methionine auxotrophy of highly growth autonomous human melanoma cells. J. Cell Physiol. 149: 332-338.

Lockwood B. and Coombs G. (1991): Purification and Characterization of methionine $\gamma$-lyase from Trichomonas vaginalis. Biochem. J. 279: 675-682.

Lopez C., Rios S.D., Lopez-Santin J., Caminal G. and Alvaro G. (2010): Immobilization of PLP-dependent enzymes with cofactor retention and enhanced stability. Biochem. Engin. J. 49: 414-421.

Luka Z., Capdevila A., Mato J.M. and Wagner C. (2006): A glycine N-methyltransferase knockout mouse model for humans with deficiency of this enzyme. Transgenic Res. 15: 393-397.

Martinez-Lopez N., Varela-Rey M., Ariz U., Embade N., Vazquez-Chantada M., FernandezRamos D., Gomez-Santos L., Lut S.C., Mato J.M. and Martinez-Chantar M.L. (2008): $S$-adenosylmethionine and proliferation: new pathways, new targets. Biochem. Soci. Trans. 63: 848-852.

Matsukura S., Soejima H., Nakagawachi T., Yakushiji H., Ogawa A., Fukuhara M., Miyazaki K., Nakabeppu Y., Sekiguchi M. and Mukai T. (2003): CpG methylation of MGMT and hMLH1 promotor in hepatocellular carcinoma associated with hepatitis viral infection. British J. Cancer 88: 521-529.

Mecham J.O., Rowitch D., Wallace C.D., Stern P.H. and Hoffman R.M. (1983): The metabolic defect of methionine dependence occurs frequently in human tumor cell lines. Biochem. Biophys Res. Comm. 117: 429-434.

Metha P.K. and Christen P. (2000): The molecular evolution of pyridoxal 5'-phosphatedependent enzymes. Adv. Enzymol. 74: 129-184.

Miki K., Al-Refaie W., Xu M, Jiang P., Tan Y., Bouvet M., Zhao M., Gupta A., Chishima T., Shimada H., Makuuchi M., Mossa A.R. and Hoffman R.M. (2000a): Methioninase gene therapy of human cancer cells is synergistic with recombinant methioninase treatment. Cancer Res. 60: 2696-2702.

Miki K., Xu M., An Z., Wang X., Yang M., Al-Refaie W., Sun X., Baranov E., Tan Y., Chishima T., Shimada H., Mossa A.R. and Hoffman R.M. (2000b): Survival efficacy of the combination of the methioninase gene and methioninase in a lung cancer orthotopic model. Cancer Gene Therp. 2: 332-338.

Miki K., Xu M., Gupta A., Ba Y., Tan Y., Al-Refaie W., Bouvet M., Makuuchi M., Mossa A.R. and Hoffman R.M. (2001): Methioninase cancer gene therapy with selenomethionine as suicide prodrug substrate. Cancer Res. 61: 6805-6810.

Morris M.S. (2003): Homocysteine and Alzheimer's disease. Lancet. Neurol. 2: 425-428. 
Moruzzi M.S., Marverti G., Piccini G., Frassineti C. and Monti M.G. (1993): Effect of spermine on membrane-associated and membrane-inserted forms of protein kinase C. Mol. Cell Biochem. 124: 1-9.

Motoshima H., Inagaki K., kumasaka T., Furuichi M., Inoue H., Tamura T., Esaki N., Soda K., Tanaka N., Yamamoto M. and Tanaka H. (2000): Crystal structure of the pyridoxal 5'-phosphate dependent L-methioninase $\gamma$-lyase from Pseudomonas putida. J. Biochem. 128: 349-354.

Mudd S.H., Skovby F., Levy H.L., Pettigerw K.D., Wilcken B., Pyeritz R.E., Andria G., Boers G.H.J., Bromberg I.L., Cerone R., Fowler B., grobe H., Schimidt H. and Schweitzer L. (1985): The natural history of homocysteinuria due to cystathionine $\beta$-synthase deficiency. Am. J. Hum. Genet. 37: 1-31.

Nagahama T., goeski N. and Endo M. (1998): Doxorubicin and vincristine with methionine depletion contributed to survival in the Yoshida sarcoma bearing rats. Anticancer Res. 18: 25-31.

Nakai T., Mizutani H., Miyahara I., Hirotsu K., Takeda S. and Jhee K.H. (2000): Threedimensional structure of 4-amino-4-deoxychorismate lyase from Escherichia coli. J. Biochem. 128: 29-38.

Nakamura T., Ren J., Zhu K-M., Kawara S. and Jin B. (2006): Application of the nanogold-4, 4'-bis (methanethiol) biphenyl modified gold electrode to the determina-tion of tyrosinase-catechol reaction kinetics in acetonitrile. Anal. Sci. 22: 1261-1264.

Nakayama T., Esaki N., Lee W-J., Tanaka I., Tanaka H. and Soda K. (1984): Purification and properties of L-Methioninase $\gamma$-lyase from Aeromonas sp. Agric. Biol. Chem. 48:2367-2369.

Napier M.P., Sharma S.K., Springer C.J., Bagshawe K.D., Green A.J., Martin J., Stribbling S.M., Cushen N., OMalley D. and Begent R.H.J. (2000): Antibody-directed enzyme prodrug therapy: Efficacy and mechanism of action in colorectal carcinoma. Clinical Cancer Res. 6: 765-772.

Nikulin A., Revtovich S., Morozova E., Neveskaya N., Nikonov S., Garber M. and Demidkina T. (2008): High resolution structure of methionine $\gamma$-lyase from Citrobacter freundii. Acta Crystallogr. 64: 211-218.

Nitenberg G. and Raynard B. (2000): Nutritional support of the cancer patient: issues and dilemmas. Critical Rev. Oncology Hematology, 34: 137-168.

O'Brien T.G. (1976): The induction of ornithine decarboxylase over expression is a sufficient condition for tumor promotion in mouse skin. Cancer Res. 57: 2630-2637.

Okada K., Hirotsu K., Sato M., Hayashi H. and Kagamiyama H. (1997): Three-dimensional structure of Escherichia coli branched-chain amino acid aminotransferase at $2.5^{\circ} \mathrm{A}$ resolution. J. Biochem. 121: 637-641.

Palm D., Klein H.W., Schinzel R., Buehner M. and Helmreich E.J.M. (1990): The role of pyridoxal-5-phosphate in glycogene phosphorylase catalysis. Biochemistry 29: 1099-1107.

Pasut G. and Veronese F.M. (2009): PEG-Conjugates in clinical development or use as anticancer agents: An overview. Advan Drug Delivery Reviews 61: 1177-1188.

Pasut G., Sergi M. and Veronese F.M. (2007): Anti-cancer PEG-enzymes: 30 years old, but still a current approach. Advanced Drug Delivary Reviews

Pegg A.E. (1988): Polyamine metabolism and its importance in neoplastic growth as a target for chemotherapy. Cancer Res. 48: 759-774. 
Percudani R. and Peracchi A. (2003): Agenomic overview of pyridoxal-phosphate dependent enzymes. EMBO Reports 4: 850-854.

Persson L., Wallstrom E.L. and Nasizadeh S. (1998): Regulation of mammalian ornithine decarboxylase. Biochem. Soc. Tran. 26: 575-579.

Poirson-Bichat F., Lopez R., Bras Goncalves R.A., Miccoli L., Bourgeois Y., Demerseman P., Poisson M., Dutrillaux B. and Poupon M.F. (1997): Methionine deprivation and methionine analogs inhibit cell proliferation and growth of human xenografted gliomas. Life Sci. 60: 919-931.

Poirson-Bichat F., Bras Goncalves R.A., Miccoli L., Dutrillaux B. and Poupon M.F. (2000): Methionine Depletion Enhances the Antitumoral Efficacy of cytotoxic agents in Drug-resistant Human Tumor Xenografts. Clinical Cancer Research 6: 643-653.

Predmore B.L. and Lefer D.J. (2010): Development of hydrogen sulfide-based therapeutics for cardiovascular disease. J. Cardiovascular Transl. Res. 3: 487-498.

Pullon D.H.H. (1980): Homocystinuria and other methioninemias, in neonatal screening for inborn errors of metabolism, edited by Bickel H, Guthrie R, hammersen G, New York, Springer-Verlag, pp: 29-44.

Razin A. and Riggs A.D. (1980): DNA methylation and gene function. Science (Washington DC), 210: 604-610.

Reddy K.R. (2000): Controlled-release, pegylation, liposomal formulations: new mechanisms in the delivery of injectable drugs. Ann. Pharmacother. 34 915-923.

Richard J.P. and Amyes T.L. (2004): On the importance of being zwitterionic: enzymic catalysis of decarboxylation and deprotonation of cationic carbon. Bioorg. Chem. 32: 354-366.

Saha B., Mukherjee S. and Das A.K. (2009): Molecular characterization of Mycobacterium tuberculosis cystathionine gamma synthase-Apo-and holoforms. Internat. J. Biological Macromol. 44: 385-392.

Santini V., Kantarjian H. and Issa J.P. (2001): Changes in DNA methylation in neoplasia: Patho-physiology and therapeutic implications. Annual Intern. Med. 134: 573-586.

Sato D., Yamagata W., Harada S. and Nozaki T. (2008): Kinetic characterization of methionine $\gamma$-lyase from the enteric protozoan parasite Entamoeba histolytica against physiological substrates and trifluoromethionine, a promising lead compound against amoebiasis. FEBS J. 275: 548-560.

Sato D. and Nozaki T. (2009): Methionine gamma-lyase: the unique reaction mechanism, physiological roles, and therapeutic applications against infectious disease and cancers. IUBMB Life 61: 1019-1028.

Schirch D., Fratte D. Lurescia S., Iurescia S., Angelaccia S. Contestabile R. Bossa F. and Schirch V. (1993): Function of the active site lysine in Escherichia coli serine hydroxmethyltransferase. J. Biological Chem. 268: 23132-23138.

Schuh S., Rosenblatt D.S. and Cooper B.A. (1984): Homocysteinuria and megaloblastic anemia responsive to vitamin B12 therapy. N. Eng. J. Med. 310: 686-690.

Scott C.B., Dorsey W.S. and Huffman H.C. (1955): Methyl mercaptan from methyl chloride. Industr. Engin. Chem. 47: 876-877.

Sharma S.K., Begshawe K.D. and Begent R.H.J. (2005): Advances in antibody-directed enzyme prodrug therapy. Current Opin. Investig. Drugs 6: 611-615.

Shaw J.P. Petsko G.H. et al., (2000): Determination of the structure of alanine racemase from Bacillus stearothermophilus at $1.9^{\circ} \mathrm{A}$ resolution. Biochemistry 36: 1329-1342. 
Soda A., Tanaka, H. and Esaki N. (1983): Multifunctional biocatalysis: methionine- $\gamma$-lyase. Trends Biochem. Sci. 8: 214-217.

Sprang S. and Fletterick R.J. (1979): The structure of glycogen phosphorylase alpha at $2.5^{\circ} \mathrm{A}$ resolution. J. Mol. Bio. 131: 523-551

Stener P.D. and Springer C.J. (2001): Selective activation of anticancer prodrugs by monoclonal antibody-enzyme conjugates. Adv. Drug. Deliv. 53: 247-264.

Stern P.H., Wallace C.D. and Hoffman R.M. (1984): Altered methionine metabolism occurs in all members of a set of diverse human tumor cell lines. J. Cell Phys. 119: 29-34.

Stewart RA, Lasis E (1965) US. Patent 3,196,143, July 20, 1965

Stipanuk M.H. (2004): Sulfur amino acid metabolism: pathways for production and removal of homocysteine and cysteine. Ann. Rev. Nutr. 24: 539-577.

Sugio S., Petsko G.A., Manning J.M. and Soda D. (1995): Crystal structure of a D-amino acid aminotransferase: How the protein controls stereoselectivity. Biochemistry, 34: 9661-9669.

Sun X., Yang Z., Li S., Tan Y., Zhang N., Wang X., Yagi S., Yoshioka T., Takimoto A., Mitsushima K., Suginaka A., Frankel E.P. and Hoffman R.M. (2003): In vivo efficiency of recombinant methioninase is enhanced by the combination of polyethylene glycol conjugation and pyridoxal 5-phosphate supplementation. Cancer Res. 63: 8377-8383.

Sun L., Hui A.M., Kanai Y., Sakamoto M. and Hirohashi S. (1997): Increased DNA methyltransferase expression is associated with an early stage of human hepatocarcinogenesis. Jpn. J. Cancer Res. 88: 1165-1170.

Swisher E.M., Gonzalez R.M., Taniguchi T., Garcia R.L., Wash T., Goff B.A. and Welcsh P. (2009): Methylation and protein expression of DNA repair genes: association with chemotherapy exposure and survival in sporadic ovarian and peritoneal carcinomas. Mol Cancer 8: 1-11

Tan Y., Sun X., Xu M., An Z., Tan X., Tan X., Han Q., Miljkovic D.A., Yang M. and Hoffaman R.M. (1998) : Polyethylene glycol conjugation of Recombinant methioninase for cancer therapy. Protein Expr. Purif. 12: 45-52.

Tan Y., Xu M., Guo H., Sun X., Kubota T. and Hoffman R.M. (1996): Anticancer efficiency of methioninase in vivo. Anticancer Res. 16: 3931-3936

Tanaka H., Esaki N. and Soda K. (1977): Properties of L-methionine $\gamma$-lyase from Pseudomonas ovalis. Biochem. 16: 100-106.

Thomas D., Barbey R. and Surdin-Kerjan Y. (1997): Gene enzyme relationship in the sulfate assimilation pathway of Saccharomyces cerevisiae. Study of the 3phosphoadenosylsulfate reductase structural gene. J. Biol. Chem. 265: 15518-15524.

Thornton J.M., Todd A.E., Milburn D., Borkakoti N. and Orengo C.A. (2000): From structure to function: approaches and limitations. Nature Struct. Biol. 7: 991-994.

Toney M.D. (2005): reaction specificity in pyridoxal phosphate enzymes. Arch. Biochem. Biophys 433: 279-287.

Tover J., Leon-Avila G., Sachez L.B., Sutak R., Tachezy J., Van der Giezen M., Hernadez M., Muller, M. and Lucocq J.M. (2003): Mitochondrial remnant organelles of Giardia function in iron-sulphur protein maturation. Nature 426: 172-176.

Vellard M. (2003): The enzyme as drug: application of enzymes as pharmaceuticals. Curr. Opin Biotechnol. 14: 444-450.

Veronese F.M. and Harris J.M. (2002): Theme issue on peptide and protein PEGylation I. Adv. Drug Deliv. Rev. 54: 453-609. 
Veronese F.M. and Pasut G. (2005): PEGylation, successful approach to drug delivery. Drug Discovery Today 21: 1451-1458.

Wald D.S., Law M. and Morris J.K. (2002): Homocysteine and cardiovascular disease: evidence on causality from a meta-analysis. BMJ 325: 1202-1206.

Wang J. and Hegele R.A. (2003): Genomic basis of cystahioninuria (MIM 219500) revealed by multiple mutations in cystathionine gamma lyase (CTH). Human Genetic 112: 404408.

Wang R. (2002): Two's Company, three's a crowd: can $\mathrm{H}_{2} \mathrm{~S}$ be the third endogenous gaseous transmitter? FASEB J. 16: 1792-1798.

Watson K.A., McCleverty C., Germia S., Cottaz S., Driguez H. and Johnson L.N. (1999): Phosphorylase recognition and phosphorolysis of its oligosaccharide substrate: Answers to a long outstanding question. EMBO J. 18: 4619-4632.

Welirnan H.B. (1966) U. S. Patent 3, 236, 046, Feb. 22.

Yamamoto N., Gupta A., Xu M., Miki K., Tsugimoto Y., Tsuchiya H., Tomita K., Mossa A.R. and Hoffman A.R. (2003): Methioninase gene therapy with selenomethionine induces apoptosis in bcl-2-overproducing lung cancer cells. Cancer Gene Therp. 10: 445-450.

Yang Z., Wang J., Yoshioka T., Li B., Lu Q., Li S., Sun X., Tan Y., Yagi S., Frankel E.P. and Hoffman R.M. (2004): Pharmacokinetics, methionine depletion, and antigenicity of recombinant methioninase in primates. Clinical Cancer Res. 10: 2131-2138.

Yang Y-Q., Yuan Y-Z., Dai S-J., Wang B. and Zhang H-B. (1998): The catalytic properties of supported K2MoS4/SiO2 catalyst for methanethiol synthesis from high $\mathrm{H}_{2} \mathrm{~S}$ content syngas. Catalysis Lett. 54: 65-68.

Yoshimura M., Nakano Y. and Koga T. (2002): L-Methionine-gamma-lyase, as a target to inhibit malodorous bacterial growth by trifluoromethionine. Biochem. Biophys. Res. Commun. 292: 964-968.

Yoshioka T., Wada T., Uchida N., Maki H., Yoshida H., Ide N., Kasai H., Hojo K., Shono K., Maekawa R., Yagi S., Hoffman R.M. and Sugita K. (1998): Anticancer efficiency in vivo and in vitro, synergy with 5-fluorouracil, and safety of recombinant methioninase. Cancer Res. 58: 2583-2587.

Zalipsky S. (1995): Functionalized poly(ethylene glycol) for preparation of biologically relevant conjugates. Bioconjug. Chem. 6: 150-165.

Zhao R., Domann F.E., Zhong W. (2006): Apoptosis induced by selenomethionine and methioninase is superoxide-mediated and p53-dependent in human prostate cancer cells. Mol. Cancer Therp. 5: 3275-3284.

Zhu W., Lin A. and Banerjee R. (2008): Kinetic properties of polymorphic variants and pathogenic mutants in human cystathionine $\gamma$-lyase. Biochemistry 47: 6226-6232.

Zou C. G. and Banerjee R. (2005): Homocysteine and redox signaling. Antioxidant Redox Sig. 7: 547-559.

Zygmunt W.A. and Tavormina P.A. (1966): Dl-S-Trifluoromethyl-homocysteine, a novel inhibitor of microbial growth. Can. J. Microbiol. 12: 143-148. 


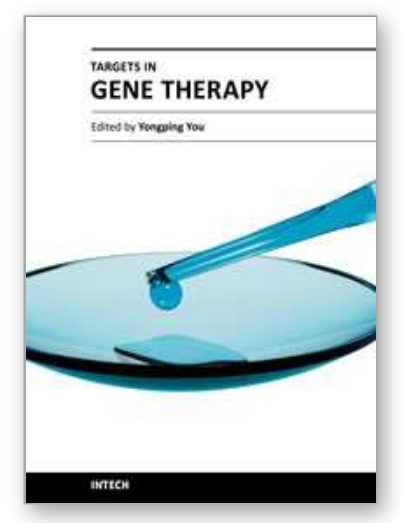

\author{
Targets in Gene Therapy \\ Edited by Prof. Yongping You
}

ISBN 978-953-307-540-2

Hard cover, 436 pages

Publisher InTech

Published online 23, August, 2011

Published in print edition August, 2011

This book aims at providing an up-to-date report to cover key aspects of existing problems in the emerging field of targets in gene therapy. With the contributions in various disciplines of gene therapy, the book brings together major approaches: Target Strategy in Gene Therapy, Gene Therapy of Cancer and Gene Therapy of Other Diseases. This source enables clinicians and researchers to select and effectively utilize new translational approaches in gene therapy and analyze the developments in target strategy in gene therapy.

\title{
How to reference
}

In order to correctly reference this scholarly work, feel free to copy and paste the following:

Ashraf S. El-Sayed and Ahmed A. Shindia (2011). PLP-Dependent Enzymes: a Potent Therapeutic Approach for Cancer and Cardiovascular Diseases, Targets in Gene Therapy, Prof. Yongping You (Ed.), ISBN: 978-953307-540-2, InTech, Available from: http://www.intechopen.com/books/targets-in-gene-therapy/plp-dependentenzymes-a-potent-therapeutic-approach-for-cancer-and-cardiovascular-diseases

\section{INTECH}

open science | open minds

\section{InTech Europe}

University Campus STeP Ri

Slavka Krautzeka 83/A

51000 Rijeka, Croatia

Phone: +385 (51) 770447

Fax: +385 (51) 686166

www.intechopen.com

\section{InTech China}

Unit 405, Office Block, Hotel Equatorial Shanghai

No.65, Yan An Road (West), Shanghai, 200040, China 中国上海市延安西路65号上海国际贵都大饭店办公楼 405 单元

Phone: +86-21-62489820

Fax: $+86-21-62489821$ 
(C) 2011 The Author(s). Licensee IntechOpen. This chapter is distributed under the terms of the Creative Commons Attribution-NonCommercialShareAlike-3.0 License, which permits use, distribution and reproduction for non-commercial purposes, provided the original is properly cited and derivative works building on this content are distributed under the same license. 